\title{
Copper mining in the Bronze Age at Mynydd Parys, Anglesey, Wales
}

\author{
By DAVID A. JENKINS \\ With contributions by SIMON TIMBERLAKE, ANDREW DAVIDSON, KALLA MAL, \\ PETER MARSHALL, TIM MIGHALL, CHARLOTTE O'BRIEN and DAVID N. SMITH
}

\section{Summary}

The Bronze Age is defined by the first extensive use of the metal copper. Prehistoric mining for this metal has been identified in surface and underground workings in Parys Mine, Mynydd Parys, Anglesey, although almost all of the surface workings are now obscured by the extensive deep spoil from more recent mining in the industrial period. These copperbearing ores are in bedded lodes, together with some intruded vein deposits. The Bronze Age workings have been exposed underground where they have been intersected by the early 19th century industrial workings on the 16 fm (fathom) level in the Parys Mine. Spoil exposures contain stone hammers ("mauls"), wood fragments and charcoal; samples of the latter have been radiocarbon dated with chronological modelling suggesting activity taking place in the first half of the second millennium cal BC. Although relatively limited in extent these important prehistoric mining sites are among the earliest found in the UK. They have survived due to their protection from surface erosion and limited accessibility.

Keywords: copper mining, Bronze Age, Mynydd Parys, radiocarbon dating

\section{INTRODUCTION}

In Britain the Early Bronze Age is dated to the period c. 2300-1600 cal BC, and by c. 2100 cal BC copper was being regularly alloyed with up to $10 \%$ tin to produce bronze (Timberlake $\&$ Marshall 2013). Accompanying the increase in metal use was a search to find more local sources of copper ore to supply this rapidly expanding industry. The discovery of major Bronze Age copper mining sites in Britain languished well behind the typological and technological study of metal artefacts, at least until the end of the 1980s, when extensive underground workings dating to the Bronze Age were first reported from the Great Orme Head, near Llandudno in North Wales (James 1988; 1990; Jenkins \& Lewis 1991; Dutton \& Fasham 1994) and from an opencast mine at Cwmystwyth in West Wales (Timberlake 1987; Timberlake and James 2018). The surface exploitation of copper ores across Western Britain has now been shown to have been more widespread than this, with up to 16 Early Bronze 
Age mines and prospecting sites identified from the Plynlimon (Plumlumon) district (midWales), the North Wales coast and the Southern Pennines of England (Alderley Edge and Ecton); most of this activity dates to the period c. 1950-1650 cal BC (Timberlake 2009; 2014; 2016). Mynydd Parys in Anglesey is unusual — and fortunate — in having associated evidence for underground mining.

The present paper describes the underground workings that have been identified, investigated, surveyed and dated in the Parys Mine. This became possible following the renewal of access to the mines in 1995, their access having been capped in 1980 for insurance reasons (Jenkins 1995). Following a brief outline of the site's location, geological context, and more recent mining history, these underground archaeological mine deposits form the subject of this paper.

\section{THE BACKGROUND TO PREHISTORIC MINING ON MYNYDD PARYS}

Mynydd Parys (Parys Mountain) is a low (146 m O.D.) but prominent mountain comprising a band of hard rocks (rhyolites, silicified shales) within the region's softer rocks (shales). It is located a few kilometres inland to the south of the town of Amlwch on the coast of Anglesey (Ynys Môn) in north-west Wales (Fig. 1). The nature of mining on Mynydd Parys in recent times, and indeed in prehistory, relate to the origin, nature, and spatial distribution of various ores. These arise from geological factors described in more detail elsewhere (Jenkins 2015, 77). The copper mined is mainly in the form of lodes along bedding planes and was formed by volcanic activity some 390 million years ago, but was also deposited in later veins along fault zones. These lodes consist of the mineral chalcopyrite $\left(\mathrm{CuFeS}_{2}\right)$ accompanied by quartz $\left(\mathrm{SiO}_{2}\right)$, often as a fine-grained mixture (known as "Bluestone", or in Welsh as "Carreg Las"), together with zinc sulphide ( $\mathrm{ZnS}$ - sphalerite) and minor lead sulphide ( $\mathrm{PbS}$ - galena).

Early references to the mineral deposits here date back to 1607 when Sir John Wynn of Gwydir recorded the presence of copperas (iron or copper sulphate) and brimstone (sulphur) on the mountain; he also noted the existence of 'a great mineral work' in 1579 from which Mr Hedley obtained a 'mineral water' that made 'alome and copperas and transmuted iron into copper' (NLW 1926, 75-77; Harris 1964, 19; North 1962, 60). There is also mention of a mine at 'Trysclwyn' in 1698 (Dodd 1926, 92), whilst Lewis Morris (1748, 3-4) refers to the presence of 'okery earths' suitable for use as a paint. Rutty $(1761,470)$ draws attention to the medicinal value of the iron-rich waters. However, the first discovery of copper ores on the mountain was by the landowner Sir Nicholas Bayly and Charles Roe \& Co. of Macclesfield at a place called Golden Venture, recorded (and subsequently celebrated) as being March $2^{\text {nd }}$ 
(St. Chad's Day) 1768 (Harris 1964, 22). The excavated ore from these works was carted down to the small harbour at Porth Amlwch that developed concurrently with the mines, and from there it was shipped to Swansea or across to Ravenshead in Lancashire for smelting and sale (Hope 1994). In the early Industrial Revolution Mynydd Parys became a major site of mining which briefly dominated world copper production for around a decade at the end of the 18th century (Rowlands 2002). Production reached 44,000 tons of copper ore per annum, surpassing that of Falun in Sweden, which had previously dominated world copper trade. A very useful account of the underground operation and working conditions at the mines at this time is provided by Michael Faraday who visited the Parys Mine during his tour of Wales in 1819 (Tomas 1972, 78-89). By the 1880s, the workforce at Mynydd Parys had shrunk from over a thousand to a few hundred and, in common with other metal mines in Britain; the mines had effectively ceased production (Harris 1964).

The ores were extracted initially from numerous shallow shafts (approximately 30-40 m deep) that later merged into the two separately owned impressive opencasts seen today (Fig. 1). Mona Mine on the east side was owned by Nicholas Bayly, and Parys Mine on the west jointly by Bayly and Reverend Edward Hughes (Rowlands 2002). From 1778 the latter was successfully worked for more than a decade by the Parys Mine Company under the management of Thomas Williams of Llanidan, known locally as 'The Copper King' (Harris 1964). Later shafts were developed to extract ore at greater depths up to a maximum of $330 \mathrm{~m}$ deep at the northern edge of the ore field. The resulting Parys and adjacent Mona Mines comprise many kilometres of passages, and extend to a depth of $156 \mathrm{fm}$ at Gwen's Shaft, but they are now flooded and inaccessible below the $45 \mathrm{fm}$ level. In the early twentieth century, another later minor phase of mine development and ore production took place by John Taylor \& Co. Ltd, whilst more recently the mines have been under evaluation by Anglesey Mining plc., through a programme of borehole drilling for possible renewed production of zinc, copper, and minor lead (AMC 2005).

All access to the underground workings was closed for insurance reasons in 1980 by the sealing of more than 100 shafts and adits with concrete caps. However, it was appreciated that there might be evidence for prehistoric mining within the underground workings, particularly since a hammer stone (then unrecognised as such) had been recovered in the 1970s from an underground site before access was closed. It was used as a convenient doorstop before its significance was recognised, ten years later, as a stone hammer or "maul" which is now considered as a likely indicator of prehistoric mining. Indeed, it was by then appreciated that these underground workings could provide the best opportunity for locating 
such mining in view of the extensive deep surface cover of later 18th-19th century spoil. In 1995 the Marquess of Anglesey kindly granted permission for the footway to Parys mine to be reopened to allow renewed access to the underground workings for survey and research purposes (Jenkins 1995, 35).

\section{THE BRONZE AGE WORKINGS AT PARYS MINES}

\section{Background}

Indications of an 'earlier' phase of mining on Mynydd Parys were suggested by Thomas Pennant in 1770 and by Christopher Sykes in 1796 (Sykes 1796, 59; Briggs 1976). Sykes was the first to recognise the form of these fireset excavations and associated spoil dumps containing the characteristic stone tools described later in this paper. Locations of four such sites are recorded on an estate map of 1764 (Hawarden Record Office D/KK/534) and are shown in Fig. 2. The prehistoric sites on the mountain so far recorded correspond to three of those identified on the 1764 map (sites 1, 3 and 4). Site 2, at Henwaith to the east (SH 4506 $9075)$, is located in what is now a private garden although early 18th century workings have recently been investigated and recorded nearby.

The observations by Sykes and others prompted a visit by Oliver Davies during his national survey of ancient mines, under the auspices of a committee set up by the British Association for the Advancement of Science in 1935 to investigate the remains of early mining in Wales (Davies 1939, 40). His excavation of spoil at Site 1, at Oxen Quarry in the area of Mona Mine just to the north of the summit (SH443906), revealed charcoal-rich sediments containing stone hammers (Davies 1939). In 1988 Oliver Davies's site was located and his original trench re-excavated by the Early Mines Research Group (EMRG) leading to the recovery of more than 30 stone tools together with charcoal fragments (Timberlake 1988).

The charcoal subsequently produced three statistically consistent radiocarbon determinations at the $5 \%$ level $\left(\mathrm{T}^{\prime}=0.8 ; \mathrm{T}^{\prime}(5 \%)=6.0 ; \mathrm{v}=2 ;\right.$ Ward \& Wilson 1978) suggesting activity in the first quarter of the second millennium cal BC; the Early Bronze Age (Timberlake 1989). These have now been supplemented by a further nine dates, from workings underground (Table 1). The three other sites recorded on the 1764 map are now buried beneath considerable depths (up to $10 \mathrm{~m}$ ) of later 19th century industrial spoil (Fig. 2). The location and nature of the original ore deposits mined in the Bronze Age is not evident. No shallow deposits of ore, nor records of such, have been found in the present study and none have been observed immediately underground. Evidence of small surface excavations that might have provided Bronze Age spoil could be submerged under present-day ponded 
surface water, and although shallow old workings (Drift Mawr), to the north of the Mona Opencast (Fig. 2), are recorded, these have not yet been located underground since entry was apparently by shafts that are now capped and inaccessible.

The underground prehistoric workings, which are the focus of this report, were discovered when permission to re-open the Parys footway was kindly given by Lord Anglesey (Jenkins 1995), which led to the subsequent exploration and survey of passages and chambers located on the $16 \mathrm{fm}$ and $20 \mathrm{fm}$ levels in Parys Mine, about $29 \mathrm{~m}$ and $36 \mathrm{~m}$ underground.

The prehistoric miners recognised outcrops of at least two of the major ore bodies in this area of the mountain, namely the Carreg-y-doll and North Discovery lodes. Two specific underground sites have been identified. The first is an impressive inclined open passage on the Carreg-y-doll lode (S3), the second is a cluster of linked workings on the North Discovery lode at the $16 \mathrm{fm}$ level (S1, S2, and S4) together with associated deposits also containing mauls at the $20 \mathrm{fm}$ level (S5 and S6). Additional prehistoric material has been identified elsewhere on the $20 \mathrm{fm}$ level (S7), but this appears to have derived from collapse from the 16 fm workings above rather than being in situ (Figs 2 and 3).

\section{The morphology of the underground excavations}

The distribution and morphology of the underground workings have been established by continuing exploration and survey over the last fifteen years and it is apparent they were originally exposed when intersected by mining 'stopes' (work chambers) driven up-dip from the $16 \mathrm{fm}$ and $20 \mathrm{fm}$ levels by 19th century miners (Fig. 3). The workings are not extensive in nature, with a limited passage length of a few hundred metres as compared to those, for example, in the Great Orme mines where kilometres of passages have been identified (Jenkins \& Lewis 1991; Lewis 1996). They do, however, indicate that the prehistoric miners were able to mine through hard and resilient rock types (argillites and silicified stockwork respectively), and to depths of many metres, although actual values are difficult to measure because of the unknown contemporary ground surface level and thickness of later overlying spoil. Furthermore, they provide a valuable insight into prehistoric mining technique in this distinctive and unusual ore field.

\section{The North Discovery Lode sites}

Sites S1, 2, 4, and 5 are clustered around what is described on the 1764 survey (Hawarden Record Office D-KK-534-03) as "Old Roman Works" on the North Discovery lode. This is 
now indicated by a $5 \mathrm{~m}$ deep conical depression in thick surface spoil, but from underground observations it appears to have been a chasm some $20 \mathrm{~m}$ by $10 \mathrm{~m}$ in size, now filled in by loose recent spoil. Sites S2 to S5 take the form of 'windows' intersected by the 18th-19th century workings whilst at S1 a sizeable work chamber was broken into and re-excavated in the early 19th century, some $10 \mathrm{~m}$ from the 'chasm', and this provides the principle section through the prehistoric spoil, which is described in detail below. Site S2 is a small inaccessible cavity in the roof of a passage nearby, whilst S4 is a small roof chamber at the edge of the "Roman shaft" and blocked by its spoil. The "window' located high up in the 20 fm workings (S5) is limited to an infilling of spoil of approximately $2 \mathrm{~m}$ by $1 \mathrm{~m}$ in extent and, from the survey, appears to be at the same level as sites S1 to S4 and only a few metres to the north.

\section{The Carreg-y-doll lode site.}

Site S3 on the Carreg-y-doll lode differs from those on the North Discovery lode; here the 18th-century workings intersected the bottom of a sloping open passage extending up-dip some $15 \mathrm{~m}$ before becoming choked with spoil (Fig. 3). Draughts observed under strong surface wind conditions suggests its choked end must be close to the surface, which survey again locates in an area under surface spoil. A possible model for the working of this type of inclined opencast-drift exploitation is shown in Fig. 4.

\section{The deposits}

As is common on such sites, the main artefactual evidence is represented by angular rock spoil, the waste product of mining, back-filling or infilling (through slumping) the excavated workings.

Ore is evident on the roof of the 18th-19th-century work chamber below S1 as sinuous quartz veins carrying chalcopyrite, weathering to a green stain of brochantite. However, a 5 $\mathrm{kg}$ sample of spoil examined from S3 was notably devoid of copper ore, suggesting either the efficiency of its recovery or that the site was excavated for access not production.

Surprisingly, the only ore found was a sample of bluestone (the mixed lead/zinc/copper ore) supporting the former suggestion and implying this ore was rejected by the early copper miners.

Spoil may provide evidence of the method of mining and also of any subsequent treatment. Such methods may be recorded in the particle size and shape in relation to the rock type involved, particle size being plotted and shape being categorized by standard criteria. 
Particle size may be restricted in range and shape by the properties of the rock and by the mining procedures involved in 'development' work to access the ores; alternatively, where spoil is subsequently redistributed and perhaps mixed, it may lose such characteristics. It may also be modified by in situ 'weathering' leading to disaggregation and accumulation of finer grades at the expense of the initial material, and this is particularly true in the very acidic environment of the Mynydd Parys mines: fine products of weathering (ie clay size, $<2 \mu \mathrm{m}$ ) may be redistributed to lower horizons. Even the angular coarser spoil is variously enriched in interstitial fine-grained material (hydrous-mica/quartz/jarosite) and iron ochre by weathering or by downwash ("illuviation"), and this should be taken into account in the interpretation of the results.

The nature of the spoil is illustrated in a series of analyses of samples from the main section S1.1 (Fig. 5). Coarse angular spoil of varying grades is common and mixed/weathered spoil can also be distinguished. In particular, a sample from the base of section S1.1 comprising banded, well-sorted quartz sand (context 107) suggested the residue from some sort of crushing and washing process from which copper ore was removed. Whether this came from work carried out underground, or from sediments washed down into the workings in successive phases from above, is an interesting question. There is clearly useful information available from such data on the spoil, but unfortunately such a 'sedimentological' approach does not appear to have been employed in the study of prehistoric mining elsewhere, so comparative data remains unavailable.

In addition to the sand layer (context 107) in section S1.1, there was also a layer of finely banded clay-silt material (Fig. 5, S1.1 (context 104)) which is indicative of ponding during a quiescent spell between two phases of back-filling or natural infilling of the working with a sandier spoil. Various organic remains were identified in this horizon, including acorns, oak leaves, bracken, charcoal and an, as yet unidentified, fibrous material.

\section{Associated artefacts - stone hammers/mauls}

\section{The stone mauls/hammers}

The distinctive artefact of prehistoric mining at Mynydd Parys, as elsewhere, is the stone hammer or "maul" (Fig 6). The extreme acidity of the mine environment ( $\mathrm{pH} \leq 3$ ) would preclude survival of any bone tools, such as those found at the Great Orme. However, it is probable that bone or antler implements were used whose original presence might still be detectable as localised phosphate anomalies retained within the abundant secondary ferric 
hydrous oxide deposits in the spoil; this is likely due to the low mobility of soluble phosphate anions under the prevailing conditions, a possibility to be tested in a future project.

A sample of 136 "mauls" (or hammer stones) has been collected and examined from the mines, 42 from surface sites and 94 from underground workings: their properties are summarised in Table 2. A dozen examples have been left in situ on the surface and some 50 underground. The surface collection is clustered at particular sites (Fig. 2), recorded as "old workings" on the 1764 map of the mountain, as referred to by Sykes (1796). These sites have been re-examined and resampled by the EMRG (Timberlake 1988) and in the present study, and comprise:

(a) 'old spoil' within the Oxen Quarry excavated by Oliver Davies (1939) and by the EMRG in 1988 (Site 1 on Fig. 2).

(b) an area on the outcrop of the Carreg y Doll lode near Quarry shaft (see Fig. 2)

(c) at the Mona Footway and within the area of the adjacent EMRG surface find clusters (sites 'Z', 'X' and 'Y' (Timberlake 1988, fig.1)) (Site 4 on Fig. 2)

(d) a site in a private garden at Henwaith which was not sampled (Site 2 on Fig. 2).

Other examples have been found scattered across the northern slopes of the mountain and, rarely, in the Great [Parys] Opencast. Those recovered from underground have been revealed where 18th-19th century mining on the $16 \mathrm{fm}$ and $20 \mathrm{fm}$ levels broke upwards into shallower Bronze Age workings that exploited both the Carreg-y-Doll and North Discovery Lodes. Underground mauls are generally encrusted with hard iron ochre which has required removal by chemical treatment (dithionite/citrate buffer) before washing to allow detailed examination. The weight, dimensions and morphology of the samples have been recorded and their petrology examined by stereo-zoom microscopy at x15-x75 magnification. However, for the mostly (65\%) fine-grained ( $<1 \mathrm{~mm}$ grain size) rock types involved, the petrology is difficult to identify in hand specimen and full confirmation will require thin-section microscopy.

The mauls take the form of very well-rounded cobbles and are mostly of high sphericity, and thus conspicuous underground amongst the angular mining spoil (Fig. 6). These were presumably readily available from till as cobbles eroded by the sea and deposited on beaches. This has been investigated along the north coast of Anglesey and two possible sources so far identified. One is at Porth Helygen (SH 491 908) providing a variety of rock types including porphyries, andesites, and granites and other unidentified igneous rocks in the Irish Sea till; the other is at Porth Llanlleiana (SH 388 951) providing local Gwna meta-quartzites. Two mauls of distinctive local basal Carboniferous sandstones could be from Llanbedrgoch, some 
$10 \mathrm{~km}$ to the south east. However, a source for a distinctive pale-buff orthoquartzite used in $16 \%$ of the mauls has not yet been identified.

Cobbles would have been selected for their appropriate properties as hammers or "mauls", such as microstructural strength and absence of weaknesses (close jointing, bedding, cleavage, etc.). This is evident in the prevalence of fine-grained homogenous rock types, often showing sub-conchoidal fractures. The samples have been divided into:

(a) nearly whole cobbles,

(b) large portions of original fractured cobbles,

(c) flakes (one face usually conchoidal),

(d) smaller fragments.

The cobbles initially chosen seem to have been dominated by those of small weight showing sub-conchoidal fractures. The sample size includes cobbles up to $2 \mathrm{~kg}$ in weight and $150 \mathrm{~mm}$ in diameter, but this may be biased toward smaller sizes as a result of the preferential collection of lighter samples from underground sites.

The original use of these cobbles is evident from the flaking and battering of ends, edges, and even faces (when used as mortars or anvils), whilst over $30 \%$ show evidence for re-use in the form of secondary battering upon already fractured faces/edges. Some samples (10\%) show evidence of pecking ("rills") (Groups 2a-c Pickin 1990; Type 2A, Timberlake \& Craddock 2013) or notches (Groups 3a and b) indicative of attachment to hafts (or possibly ease of use by hand); these results are summarised in appendix Table 2. The groups present within this relatively small sample of 130 are comparable to the somewhat larger examples from Mount Gabriel and Ross Island (O’Brien 1994; 2004) and Cwmystwyth (Timberlake 2003; Timberlake \& Craddock 2013). The still larger collection of cobble stone tools (approximately 3,500) found at the Great Orme mines appear to be dominated geologically by beach pebbles derived from chilled margins of the 'micro-diorite' outcrop at nearby Penmaenmawr to the west of Llandudno, though this assemblage has yet to be studied in petrological detail (Dutton \& Fasham 1994).

\section{Dating of the deposit}

Sites S1, S2, S4, S5 and S6 (see Fig. 4) all provided suitable material for nine radiocarbon dates, together with three dates deriving from samples from the surface deposits excavated by the EMRG (Timberlake 1989) (Table 1). The section locations that the samples were recovered from in $\mathrm{S} 1$ are shown in Fig. 5. 
The radiocarbon dates on charcoal from underground spoil within the mine and from surface spoil at Oxen Quarry clearly fall into a coherent group concentrated in the first half of the second millennium cal BC. The measurements are though, not statistically consistent at the 5\% level $\left(\mathrm{T}^{\prime}=22.8 ; \mathrm{T}^{\prime}(5 \%)=19.7 ; \mathrm{v}=11\right.$; Ward \& Wilson 1978), and so they represent more than one episode of mining activity.

Simple visual inspection of the calibrated radiocarbon dates does not allow us to assess the date of mining activity at Mynydd Parys accurately, since the calibration process does not allow for the fact that this group of radiocarbon dates are related - they all come from the same site. Bayesian statistical modelling is required to account for this dependence (Buck et al. 1992; Bayliss et al. 2007), which we have undertaken using OxCal v.4.3 (Bronk Ramsey 2009) and the atmospheric calibration curve for the northern hemisphere published by Reimer et al. (2013).

The model (Fig. 7) shows good agreement (Amodel: 89) between the radiocarbon dates and assumption the mining activity took place at a uniform rate over a period of time (Buck et al. 1992). The model estimates that mining activity first took place in 2245-1785 cal BC(95\% probability; start_mynydd_parys; Fig. 10), probably 2085-1890 cal BC (68\% probability) and finished in 1815-1300 cal BC (95\% probability; end_mynydd_parys; Fig. $10)$, probably $1735-1485$ cal $B C$ ( $68 \%$ probability). The dated mining activity is estimated to have taken place over a period of $40-550$ years (95\% probability; Fig. 8) probably $175-440$ years $(68 \%$ probability).

The beginning of dated mining activity on Mynydd Parys is clearly earlier than at the Great Orme (94\% probability; Fig. 9), where the ores being mined were probably more recognisable (green and blue copper carbonates), and perhaps more easily extractable and reducible.

\section{Palaeoenvironmental evidence}

Palaeoenvironmental data was collected from sections S1.1 and S3 and processed. The conclusions are presented here, and the full report is given in Appendix II at the end of this paper.

The pollen results confirm that the Bronze Age landscape at Mynydd Parys surrounding the mine was largely open with areas of heathland and wet grassland with some pools of water (Fig. 10 and 11). Deciduous woodland was present, mainly comprising oak and hazel. A permanent decline in woodland was recorded at Site 3 with oak being most affected (Fig. 
11). Otherwise, the tree and shrub pollen record is characterised by small-scale fluctuations of oak, hazel, birch, and alder, all known to have been used in prehistoric mines.

Both pollen diagrams, drawn using Tilia and Tilia.graph version 2.0.b4 (Grimm 19911993), are presented as percentages of total land pollen (TLP), excluding spores and aquatics. Spore and aquatics are also expressed as a percentage of total land pollen. A cross denotes one pollen grain. Plant nomenclature follows that of Stace (2010) and takes into account the problems of categorising plant species on the basis of their pollen morphology (see Bennett et al. 1994). Summary curves for trees, shrubs (constituting arboreal pollen, AP), dwarf shrubs and herbs (non-arboreal pollen, NAP) are shown.

Notwithstanding taphonomic and dating issues, trends in both pollen diagrams are similar to those recorded in other pollen diagrams close to prehistoric mining and metalworking sites, in particular small-scale fluctuations of Quercus, Corylus, Alnus and Betula (Mighall \& Chambers 1993; Mighall et al. 2017). It is possible that these fluctuations are the result of exploitation of local woodland for timber and charcoal. The permanent decline in tree and shrub pollen at Site 3 contrasts with evidence from other Bronze Age mines in Wales and Ireland which suggests woodland was not severely cleared (Mighall \& Chambers 1993; Mighall et al. 2017). However, all these mines, including Mynydd Parys, did not operate in isolation and agricultural activities, in particular grazing, occurred as part of a dual economy.

\section{DISCUSSION}

The recognition of copper ores in the Bronze Age would have been determined by the nature of the landscape and its ecology, and by the distribution and nature of ore exposures. The mineralisation on the mountain is of an unusual nature for Britain, the so-called "Kuroko" type of ore deposit, leading to inter-bedded seams and scattered pods of rich ore. The host rocks comprise an Ordovician/Silurian inlier of hard fine-grained volcanic rocks (rhyolitic extrusives, intrusives and pyroclastics) often also intensely silicified in a later phase. These relatively hard rocks within the softer shales were more resistant to glacial erosion, with the result that they produced a low, but prominent, feature, Mynydd Parys, standing at $147 \mathrm{~m}$ OD above the generally planated surface of Anglesey at $70 \mathrm{~m}$ OD. As a result Mynydd Parys would have been a prominent hill or landmark within the Bronze Age landscape on Anglesey.

The appearance of exposed ores would again have been a notable feature in an otherwise 'normal' environment. Copper deposits can be recognised by the secondary copper minerals produced by weathering, but the distinctive carbonates malachite (green) and azurite (blue) 
are not stable in the acidic environment of Mynydd Parys, whilst the various sulphates are relatively soluble and would only be preserved within protected cavities and overhangs at the surface and in 'weathered' underground workings. In environmental terms, the weathering of the predominant sulphide mineral, iron pyrite $\left(\mathrm{FeS}_{2}\right)$, results in the production of a very acidic environment $(p \mathrm{H} \leq 3)$ and of a distinctive sparse vegetation comprised mainly heather and specialised lichens. The release of iron and its subsequent oxidation and deposition as a distinctive orange-brown stain upon exposed rocks would again be a distinctive feature in an otherwise 'normal' environment. Bronze Age metal miners would therefore have needed to locate the sulphide-rich rocks and to recognise the presence of copper within these sulphide and oxidised sulphide ores.

Yet another means of recognising and possibly also extracting copper during the Early Bronze Age could have been through the burning of the superficial peats accumulated within a number of poorly drained valley sites scattered across the mountain. Such deposits were in fact noted on the 1764 map where the peat was exploited in "turbaries". The chemistry of copper, released into solution by weathering of its sulphide ores in the acidic, anoxic, conditions, is such that it can form a stable metallic precipitate, visibly sheathing plants. This form of deposit was readily exploited in the 18th-19th century at mines such as Dolfrwynog in Coed y Brenin, mid Wales (Price \& Abrahams 1994, 27). Such distinctive precipitates in any early peats on Mynydd Parys would themselves have attracted attention in the Early Bronze Age and, even more so, any metallic residues left after the burning of such peat.

The intriguing question arises as to which particular ore was extracted during the Early Bronze Age. Various possibilities exist - either it was the primary copper sulphide itself (chalcopyrite), the secondary enriched copper sulphides (chalcocite and covellite), native metallic copper, or the secondary oxides, carbonates, or sulphates. Of these by far the most usable would have been native copper, although both the carbonates and oxides are relatively easily smelted to metal (Chapman \& Chapman 2013). By contrast, the recovery of copper from chalcopyrite involves a much more complex smelting process which includes preliminary roasting (oxidation to remove the sulphur) followed by reduction and slagging (for removal of iron) in order to obtain the metal. Of the secondary minerals, the brightly coloured carbonates are absent here due to the highly acidic environment, whilst the ephemeral nature of copper sulphates has already been discussed. However, secondary deposits of metallic copper are generally predictable in peaty anaerobic sites (Krauskopf \& Bird 1994), and significant occurrences of native copper were reported by Lentin in 1800 (Rothwell 2007, 10-12) and before that by Pennant (1778, 255-6) from the near-surface zone 
of the Parys orebody, whilst Greenly $(1919,837)$ noted the presence of leaf-like or moss-like aggregates of native copper present within the gossan of the Great Lode, as well as from the nearby mine at Rhosmynach; specimens of which are held within the National Museum of Wales collections (Bevins 1994).

As noted above chalcopyrite, the main copper ore at Mynydd Parys, is notably sparse within the Bronze Age spoil examined from site S1, suggesting that either it was not encountered in any great amount within the areas they were working in, or that it had been extracted selectively from these same areas with remarkable efficiency. A sample of Carreglas (bluestone) was, however, recovered from section S1, possibly after having been discarded by the Bronze Age miners, suggesting that chalcopyrite or perhaps rotten chalcopyrite (here consisting of a mixture of oxidised or enriched secondary copper minerals) was the most likely ore sought. Both the Carreg y Doll and North Discovery lodes were exploited in the Bronze Age, whilst no evidence has survived for lodes in the opencast, possibly due to the scale and intensity of later historical operations. The ores currently exposed in the opencast are now mostly dominated by zinc/lead with minor copper, presumably those rich in copper having been selectively extracted during the historic/ prehistoric period.

The provenance of the copper used to make bronze has variously been suggested on the basis of distinctive trace metal patterns in metal as discussed by Northover (1980) with respect to Wales. Northover proposed a number of Early Bronze Age metal-types, one of which he considered had its origin in north-west Wales (Group B3), which he identified by its trace metal composition $\mathrm{As}<0.75 \%, \mathrm{Ni}>0.06 \%$ and its prevalence alongside other metal types (ie Groups B1, C and A (as Irish metal)) in the period c. 2200-1600 cal BC. The actual source of this B3 copper was not ever stated, although the implication was that it might include Mynydd Parys. Analysis of such assemblages is complicated by several factors such as probable separate sources of the minor alloying elements involved (eg tin), the mixing of coppers, and the progressive dilution of any signature metal assemblage as bronzes were merged during metal recycling. However, the copper ore (chalcopyrite $-\mathrm{CuFeS}_{2}$ ) at Mynydd Parys is lacking in distinctive levels of trace metals and no derived artefacts have yet been identified which would allow comparisons of composition. Rohl \& Needham (1998) used a combination of stable lead isotope analysis of the lead compositions within artefacts and ores and the trace element patterns present in metalwork to define a set of Bronze Age implement metal (IMP-LI) groups which could then be compared with ore sources as defined for the English and Welsh ore fields (EWLIO). Once again, no clear match could be established 
between any metal type and Mynydd Parys, although chalcopyrite from here was analysed, the 'best fit' perhaps being with ores from north-west Wales and Shropshire and IMP-LI 6 (Willerby metalwork (1900-1700 cal BC) (Needham 1996)). A specific Mynydd Parys source of Early Bronze Age metal was likewise not defined by Peter Bray in his re-evaluation of evolving metal types in use in the Bronze Age, although he does refer to specific metal types appearing in Wales during the Early Bronze Age (such as DC2 (As) and DC 11 (As $+\mathrm{Ni}$ )) which he considers to be a signal for local exploitation (Bray \& Pollard 2012). The answer here may be to try and identify the exact (mineralogical/ chemical) composition(s) of the ore(s) the Bronze Age miners were removing at Mynydd Parys, by following the same (or a similar) mine-based metal type model Alan Williams has developed in his investigations of the Great Orme (Williams 2019). This approach proved remarkably effective on the Orme, but will be more difficult to attempt at Mynydd Parys on account of the very considerable alteration of the mined ore body and its wholesale removal.

Chronological modelling of the 12 radiocarbon dates taken from surface and underground samples of burnt wood associated with firesetting and from un-burnt wood associated with slumped-in/ washed-in mine sediments suggest that Early Bronze Age mining took place in the first half of the second millennium cal BC. The estimated dates obtained so far indicate that mining began in 2085-1890 cal BC (68\% probability) and ended in 1735-1485 cal BC ( $68 \%$ probability), over a period of $175-440$ years ( $68 \%$ probability), though more dates would be necessary to demonstrate whether this covers the full duration of mining across the site. The most likely scenario is that we are looking at (probably intermittent) underground mining, centred upon the earlier part of this widespread phase of prospection taking place within Western Britain at the beginning of the Bronze Age, but with dates a little later than in Central Wales.

Fig. 12 is a schematic diagram summarising the estimate dates when mining activity at sites with three or more radiocarbon dates occurred. The horizontal bars represent the probability that a particular site was in use in a 100-year-period (light shading is less probable, darker shading more probable). Distributions have been taken from the model shown in Timberlake \& Marshall (2014, fig 4). Mining activity at Mynydd Parys is broadly contemporary with that at Copa Hill, Alderley Edge and Ecton (The Lumb and Stone Quarry mine) suggesting the main flourit of early Bronze Age mine took place in the centuries either side of 2000 cal BC.

At Mynydd Parys more dates would be needed to confirm whether the surface workings at the Oxen Quarry were later than the underground ones on the North Discovery and Carreg- 
y-ddol lodes, though this may be difficult to demonstrate as some of the underground material appears to have been transported from the surface. The current chronology therefore provides a fairly robust estimate of the date of Bronze Age mining on the site. We see this same phenomenon of surface material being deposited below ground within the Comet Lode Opencast at Cwmystwyth, but in the latter case these infill sediments were only slightly (or not at all) mobilised, therefore the stratigraphical and chronological sequence appears correct, with the earliest mining debris on the bottom (Timberlake 2003, fig. 41).

Despite the evidence for Bronze Age mining from both surface and underground contexts, little in the way of further investigation of the mountain for evidence of contemporary settlement or processing sites has ever been attempted, in part due to the extreme level of disturbance encountered, and in part due to the paucity of mapping evidence prior to 1764. However, one possible prehistoric site has been identified on the south-western side of the mountain at Penyfynwent, near the hamlet of Rhosybol, a little distance from the most intensively mined area. The pentagonal earthwork is of unknown date, although it is adjacent to a small, nearly ploughed out, barrow, both perhaps being Bronze Age features. The site was examined by Simon Timberlake as a possible one for further investigation, using either geophysics or geochemistry to detect structures or the evidence for mineral processing or smelting (the latter by means of a geochemical survey of the soil similar to the one carried out on the Great Orme (Jenkins et al. 2001)), but to date none of this has been pursued. Nevertheless, a palaeoenvironmental study of the hinterland area of the mountain did include a pollen and geochemical record for a $2 \mathrm{~m}+$ core taken from the bog at Rhosybol (Fig. 13; Jenkins \& Timberlake 1997 unpubl., 87-89). This and a subsequent core revealed the Holocene history of the site from at least 8330-7580 cal BC (8870 \pm 150 BP; Beta-169435); the upper part of it showing the loss of woodland and pollution resulting from historic mining and smelting, the lower part (from $70 \mathrm{~cm}$ ) showing elevated concentrations of copper, zinc, and lead as minor releases of heavy metals probably generated by mining from the prehistoric period onwards (Mighall \& Timberlake 2006 unpubl.). The pollen data suggests that woodland cover is already quite limited between $80 \mathrm{~cm}$ and $54 \mathrm{~cm}$ but there is a small decline in tree and shrub pollen at $70 \mathrm{~cm}$. Tree and shrub percentages increase from $54 \mathrm{~cm}$ suggesting increased woodland in the local vicinity indicating that any early mining activity or agricultural activities did not have a significant impact on woodlands. A more detailed chronology of the core is needed to fully assess this evidence. Similar geochemical evidence pointing to possible prehistoric-Roman mining was recovered in 1996 from a $2.75 \mathrm{~m}$ core 
drilled through sediments at Traeth Dulas near the mouth of the Afon Goch (Timberlake \& Jenkins 2001).

The possibility of Roman mining on Mynydd Parys has been suggested on a number of different occasions by various different authors (Rowlands 2002,20). This raises a number of questions since the evidence from here is in part impressive, and in part circumstantial and indirect. This takes the form of copper cake ingots weighing on average around $20 \mathrm{~kg}(15-45$ $\mathrm{kg}$ ), some of them $30 \mathrm{~cm}$ in diameter and $5 \mathrm{~cm}$ thick (RCAHMW 1961). Added to those recorded by the RCAHMW, a total of 18 ingots have now been found at various sites across Anglesey, two of them on the flanks of Mynydd Parys itself, and one recently recovered from the Menai Strait. Three, possibly five, of these ingots bear a stamp in Roman script on an embossed dab of copper. However, despite efforts to identify and date possible underground workings in the Parys mines to the Roman period, none has yet been identified, and the current chronology does not extend beyond the Early Bronze Age. Perhaps such workings were located upon other lodes since worked out, for example within the opencasts. None of these though are indicated on the 1764 map and it would be expected that at least some traces would have been detected underground in the Carreg-y-doll and North Discovery lodes, both of which were worked during the Early Bronze Age. It is relevant that small lead ingots were apparently found in a hearth within the Great Opencast (Pennant 1778) and, although these have since been lost, scraps of highly oxidised folded lead sheeting have been found in spoil near the summit of Mynydd Parys, which are currently under investigation for their nature and age. For the present, however, any mining activity during the Iron Age and Roman times has yet to be identified.

\section{CONCLUSIONS}

The programme of exploration work undertaken at Mynydd Parys has identified evidence for surface and underground extraction of copper within the first half of the second millennium cal BC, during the Early Bronze Age. The sites are located both on the surface and underground, although at least some of the latter appear to have been reached through the excavation of opencast drifts up to $20 \mathrm{~m}$ deep. The excavations would have been undertaken using stone mauls and fire-setting techniques. Animal bone has not survived in the acidic environment, so its use, as at the Great Orme mines, can only be extrapolated from evidence elsewhere.

The chronology indicates a period of exploitation preceding that at the Great Orme, but contemporary with Irish mining and that within mid-Wales. A chronological development of 
exploitation westwards, from Ireland to central and North Wales and into north-west England, has been suggested (Timberlake \& Marshall 2014).

More work needs to be undertaken to understand the full extent of prehistoric mining at Mynydd Parys, both above and below ground. This needs to be linked to a wider review of the Beaker and Early Bronze Age landscape of north Anglesey. Other avenues of future research might include chemical analysis as developed by Williams at the Great Orme (Williams 2019) despite the inherent difficulties caused by the different chemical composition. Evidence for later exploitation of the mines during the Roman period is still lacking, despite the numerous finds of 'Roman-style' copper ingots on Anglesey.

The painstaking work to identify the Early Bronze Age workings has provided evidence for the development of copper mining at Mynydd Parys. This makes a major contribution to the relatively small number of extraction sites known, and fits in well with the chronological model currently being developed. There is considerable potential for future work at this site to further our knowledge of Early Bronze Age mining and to search for the evidence of processing sites and the earliest smelting hearths.

\section{ACKNOWLEDGEMENTS}

This article was researched and written by Dr David Jenkins. The final editing has been undertaken by Andrew Davidson and Jane Kenney (Gwynedd Archaeological Trust), and Dr Simon Timberlake (Early Mines Research Group and McDonald Institute, University of Cambridge), with contributions and corrections by Tim Mighall and Pater Marshall. Cadw generously funded the work through grant aid. The suggestion to edit and publish the article came from Dr John Llywelyn Williams, who has worked closely with David Jenkins on this and a number of other significant projects. The editors are also very grateful to help and encouragement from Paul Jenkins (David's son). Members of the Parys Underground Group and the Early Mines Research Group have helped source illustrations, and have supported the work.

\section{BIBLIOGRAPHY}

Andrew, R. 1984. A practical pollen guide to the British Flora. Technical guide 1,

Cambridge: Quaternary Research Association

A.M.C. 2005. Anglesey Mining plc Report, Amlwch, Anglesey

Barber, K.E. 1976. History of vegetation. In S.B. Chapman (ed.) Methods in Plant Ecology,

5-83. Oxford: Blackwell 
Bayliss, A., Bronk Ramsey, C., van der Plicht, J. \& Whittle, A. 2007. Bradshaw and Bayes: Towards a timetable for the Neolithic. Cambridge Archaeological Journal, 17(supplm 1), $1-28$

Bennett, K.D., Whittington, G. \& Edwards, K.J. 1994. Recent plant nomenclatural changes and pollen morphology in the British Isles. Quaternary Newsletter 73, 1-6

Bevins, R. 1994. A Mineralogy of Wales. Cardiff: National Museum of Wales

Bray, P.J. \& Pollard, A.M. 2012. A new interpretative approach to the chemistry of copperalloy objects, source, recycling and technology. Antiquity 86, 853-867

Briggs, C.S. 1976. Note on prehistoric mining in Anglesey. Historical Metallurgy 10 (1), 43

Bronk Ramsey, C. 2009. Bayesian analysis of radiocarbon dates. Radiocarbon, 51(1), 337360

Buck, C.E., Litton, C.D., \& Smith, A.F.M. 1992. Calibration of radiocarbon results pertaining to related archaeological events. Journal of Archaeological Science 19(5), 497-512

Bunting, M.J., Tipping, R. \& Downes, J. 2001. “Anthropogenic" pollen assemblages from a Bronze Age cemetery at Linga Fiold, West Mainland, Orkney. Journal of Archaeological Science 28(5), 487-500

Burnham, B., Burnham, H. \& Walker, M.J.C. 1992. Excavations across the Annell and Gwenlais Leats, near Dolaucothi, in 1990. Archaeology in Wales 32, 2-8

Cambrian Caving Council 2010. Cave life of Britain. [online] Available at: http://www.cambriancavingcouncil.org.uk/cavelife/index.html [accessed 01/11/2016]

Chapman, D. \& Chapman, S. 2013. Pentrwyn Bronze Age copper smelting site: Reconstructing and using the Pentrwyn pit furnaces. Ancient Arts (unpublished report)

Crew, P. \& Crew, S. (eds) 1990. Early Mining in the British Isles. Proceedings of the Early Mining Workshop at Plas Tan y Bwlch Snowdonia National Park Study Centre, 17-19 November, 1989, Tan y Bwlch Occasional paper no.1

Cushing, E.J. 1967. Evidence for differential pollen preservation in Late Quaternary sediments in Minnesota. Review of Palaeobotany and Palynology 4, 87-101

Davies, O. 1939. Excavations on Parys Mountain. Transactions of Anglesey Antiquarian Society and Field Club 1939, 40-42

Delcourt, P.A. and Delcourt, H.R. 1980. Pollen preservation and Quaternary environmental history in the southeastern United States. Palynology, 4(1), 215-231

Dodd, A.H. 1926. Parys Mountain during the Industrial Revolution 1760-1840. Transactions of the Anglesey Antiquarian Society, 90-105 
Dutton, L.A. \& Fasham, P.J. 1994. Prehistoric Copper Mining on the Great Orme, Llandudno, Gwynedd. Proceedings of the Prehistoric Society 60, 245-86

Fægri, K. Kaland, P.E. and Krzywinski, K. 1989. Textbook of pollen analysis 4th edition. Chichester: John Wiley and Sons

Gale, R. \& Cutler, D. 2000. Plants in archaeology; identification manual of vegetative plant materials used in Europe and the southern Mediterranean to c.1500. Kew: Westbury and Royal Botanic Gardens, Kew

Greenly, E. 1919. The Geology of Anglesey, 2 vols, Memoirs of the Geological Survey

Grimm, E. 1991-1993. TILIA and TILIA.GRAPH. Illinois: Illinois State Museum

Hall, A. 2003. Recognition and characterisation of turves in archaeological occupation deposits by means of macrofossil plant remains. Centre for Archaeology Report 16/2003. Historic England

Harris, J.R. 1964. The Copper King. Liverpool: Liverpool University Press

Hope, B.D. 1994. A Curious Place, The Industrial History of Amlwch (1550-1950).

Wrexham: Bridge Books

Hudson, H. J. 1986. Fungal Biology. London: Edward Arnold

Hyman, P and Parsons M.S. 1992. A Review of the Scarce and Threatened Coleoptera of Great Britain (U.K. Nature Conservation Volume 3). Peterborough: UK Joint Nature Conservation Committee

James, D. 1988. Prehistoric copper mining on the Great Ormes Head. In J. Ellis-Jones (ed.) Aspects of Ancient Mining and Metallurgy, Acta of a British School at Athens Centenary Conference, Bangor, 1986, 115-21

James, D. 1990. Prehistoric mining on the Great Ormes Head. In P. Crew \& S. Crew (eds), Early Mining in the British Isles, Plas Tan-y-Bwlch Occasional Paper no. 1, 1-4 Jenkins, D.A. 1995. Mynydd Parys copper mines. Archaeology in Wales 35, 35-37 Jenkins, D.A. 2015. Mine drainage at Mynydd Parys: an intriguing history and recent problems. In D. Linton (ed.), Mining Technology: Technical Innovation in the Extractive Industries, Proceedings of the NAMHO Conference, 2014, 77-83. Welsh Mines Society Jenkins, D.A. \& Lewis, C.A. 1991. Prehistoric mining for copper in the Great Orme. In P. Budd, B. Chapman, C. Jackson, R. C. Janaway \& B. S. Ottaway (eds), Archaeological Sciences 1989, 51-61: Oxford: Oxbow Monograph No.9 1

Jenkins, D.A., Owen, A. \& Lewis, A. 2001. A rapid geochemical survey of the Bronze Age Copper Mines on the Great Orme, In A. Millard (ed.), Archaeological Sciences '97, Oxford: British Archaeological Reports (International Series) 939, 164-69 
Jenkins, D.A. \& Timberlake, S. 1997. Geoarchaeological research into prehistoric mining for copper in Wales, A Report to the Leverhulme Trust on completion of Grant No.F/174/L, University of Bangor, North Wales (unpublished)

Jessop, L. 1986. Coleoptera: Scarabaeidae. Handbooks for the Identification of British Insects. London: Royal Entomological Society of London

Jones, J., Tinsley, H. and Brunning, R. 2007. Methodologies for assessment of the state of preservation of pollen and plant macrofossil remains in waterlogged deposits. Environmental Archaeology 12, 71-86

Kenward H. K., Hall A.R., and Jones A.K.G.1980. A tested set of techniques for the extraction of plant and animal macrofossils from waterlogged archaeological deposits. Scientific Archaeology 22: 315

Koch, K. 1989. Die Kafer Mitteleuropas. Okologie. Band 2. Krefeld

Koch, K. 1992. Die Kafer Mitteleuropas. Okologie. Band 3. Krefeld

Krauskopf, K.B. \& Bird, D.K. 1994. Introduction to Geochemistry, $3^{\text {rd }}$ edition

Lewis A. 1996. Prehistoric mining at the Great Orme, criteria for the identification of early mining, Unpublished MA dissertation, University of Wales, Bangor.

Lindroth, C.H. 1974. Coleoptera: Carabidae. Handbooks for the Identification of British Insects. IV. part 2. London: Royal Entomological Society of London

Lowe, J.J., and Walker, M.J.C. 1997. Reconstructing Quaternary Environments. London: Prentice Hall

Lucht, W.H. 1987. Die Käfer Mitteleuropas (Katalog). Krefeld: Goecke and Evers

Luff, M. 2007. Coleoptera: Carabidae (Handbooks for the Identification of British Insects 4/2 -Second Edition). London: Royal Entomological Society of London

Mighall, T.M., Abrahams, P.W., Grattan, J.P., Hayes, D., Timberlake, S. \& Forsyth, S. 2002a. Geochemical evidence for atmospheric pollution derived from prehistoric copper mining at Copa Hill, Cwmystwyth, mid-Wales, UK. Science of the Total Environment $292,69-80$

Mighall, T.M. \& Chambers, F.M. 1993. The environmental impact of prehistoric copper mining at Copa Hill, Cwmystwyth, Wales. The Holocene 3(3), 260-64

Mighall, T.M., Chambers, F.M., Lanting, J. \& O’Brien, W.F. 2000. Prehistoric copper mining and its impact on vegetation: palaeoecological evidence from Mount Gabriel, Co. Cork, southwest Ireland. In R.A. Nicholson\& T.P. O’Connor, (eds) Prehistoric People as Agents of Environmental Change, 19-29. Oxford: Oxbow 
Mighall, T.M. \& Timberlake, S. 2006 Prehistoric mining and its environmental context, A Report to the Leverhulme Trust on completion of Grant No. F/00/732/C, University of Coventry (unpublished)

Mighall, T.M., Timberlake, S., Clark, S.H.E. \& Caseldine, A. 2002b. A palaeoenvironmental investigation of mine infill sediments from Copa Hill, Cwmystwyth, mid-Wales. Journal of Archaeological Science 29(10), 1161-88

Mighall, T.M., Timberlake, S., Foster, I.D.L., Krupp, E. \& Singh, S. 2009. Ancient copper and lead pollution records from a raised bog complex in Central Wales, UK. Journal of Archaeological Science 36(7), 1504-15

Mighall, T., Timberlake, S., Martínez-Cortizas, A., Silva-Sánchez, N. \& Foster, I.D.L., 2017. Did prehistoric and Roman mining and metallurgy have a significant impact on vegetation? Journal of Archaeological Science: Reports 11, 613-25

Moore, P.D., Webb, J.A. \& Collinson, M.E. 1991. Pollen Analysis. 2nd edition. London: Blackwell Scientific Publications

Morris, Lewis 1748 Plans of Harbours, Bars, Bays and Roads in St. George's Channel Nakagawa, T., Brugiapaglia, E., Digerfeldt, G., Reille, M., De Beaulieu, J.-L. \& Yasunda, Y. 1998. Dense-media separation as a more efficient pollen extraction method for use with organic sediment/deposit samples: comparison with the conventional method. Boreas 27, $15-24$

National Library of Wales (NLW) 1926 Calendar of Wynn Papers

Needham, S.P. 1996. Chronology and periodisation in the British Bronze Age. Acta Archaeologica 67, 121-40

North, F.J. 1962 Mining for Metals in Wales, National Museum of Wales

Northover, J.P. 1980. The Analysis of Welsh Bronze Age Metalwork, In H.N. Savory, Guide Catalogue of the Bronze Age Collections. Cardiff: National Museum of Wales, 229-36

O’Brien, W. 1994. Mount Gabriel - Bronze Age mining in Ireland. Galway: Galway University Press

O’Brien, W. 2004. Ross Island: Mining, Metal and Society in Early Ireland. Bronze Age Studies 6. Galway: National University of Ireland

Pennant, T. 1778. A tour in Wales MDCCLXXVIII: The tour in North Wales. London Pickin, J. 1990. Stone tools and early metal mining in England and Wales. In Crew, P. \& Crew, S., 39-42

Preston, C.D., Pearman, D.A. \& Dines, T.D. 2002. New Atlas of the British and Irish Flora. Oxford: Oxford University Press 
Price, G.P. \& Abrahams, P.W. 1994. Copper tolerance in a population of Silene vulgaris ssp. maritima at Dolfrwynog Bog near Dolgellau, North Wales. Environmental Geochemistry and Health 16 (1), 27-30

RCAHMW 1961. An inventory of the ancient monuments in Anglesey (reprint). London: The Royal Commission on Ancient and Historic Monuments in Wales and Monmouthshire, HMSO

Reille, M. 1992. Pollen et spores D'Europe et D'Afrique du Nord. Editions du Laboratoire de botanique historique et palynologie. Marseille

Reimer, P.J., Bard, E., Bayliss, A., Beck, J.W., Blackwell, P.G., Bronk Ramsey, C., Grootes, P.M., Guilderson, T.P., Haflidason, H., Hajdas, I., Hatt, C., Heaton, T.J., Hoffmann, D.L., Hogg, A.G., Hughen, K.A., Kaiser, K.F., Kromer, B., Manning, S.W., Niu, M., Reimer, R.W., Richards, D.A., Scott, E.M., Southon, J.R., Staff, R.A., Turney, C.S.M., \& van der Plicht, J. 2013. IntCal13 and Marine13 radiocarbon age calibration curves 0-50,000 years cal BP. Radiocarbon, 55(4), 1869-87

Robinson, M.A. 1981. The use of ecological groupings of Coleoptera for comparing sites. In M. Jones and G. Dimbleby (eds) The Environment of Man: The Iron Age to the AngloSaxon Period, Oxford: British Archaeological Reports (British Series) 87, 251-86

Robinson, M.A. (1983). Arable/ pastoral ratios from insects? In M. Jones (ed.) Integrating the Subsistence Economy, Oxford: British Archaeological Reports (International Series), 19-47 (s 181)

Rohl, B. \& Needham, S. 1998. The Circulation of Metal in the British Bronze Age: The Application of Lead Isotope Analysis. British Museum Occasional Paper No.102, British Museum Press

Rothwell, N. 2007. Parys Mountain and the Lentin Letters. Amlwch: Printworks.

Rowlands, J. 2002. The Copper Mountain (Revised edition). Anglesey: Stone Science Rutty, J. 1761. Of the vitriolic waters of Amlwch in the Isle of Anglesey. Philosophical Transactions of the Royal Society 51, 470-77

Stace, C. 2010. New flora of the British Isles. Cambridge: Cambridge University Press

Sykes, C. 1796. Journal of a tour in Wales MS.2258C (Typescript copy), National Library of Wales

Timberlake, S. 1987. An archaeological investigation of early mineworkings on Copa Hill, Cwmystwyth. Archaeology in Wales 27, 18-20

Timberlake, S. 1988. Excavations at Parys Mountain and Nantyreira. Archaeology in Wales 28, 11-17 
Timberlake, S. 1989. Parys Mountain and Nantyreira C14 dates. Archaeology in Wales 29, 41-42

Timberlake, S. 2003. Excavations on Copa Hill, Cwmystwyth 1989-99: An Early Bronze Age Copper Mine within the Uplands of Central Wales. Oxford: British Archaeological Reports (British Series) 348

Timberlake, S. 2009. Copper mining and metal production at the beginning of the British Bronze Age. In P. Clark (ed.) Bronze Age Connections, 96-122. Oxford: Oxbow,

Timberlake, S. 2014. Prehistoric copper extraction in Britain: Ecton Hill, Staffordshire, Proceedings of the Prehistoric Society 80, 159-206

Timberlake, S. 2016. New ideas on the exploitation of copper, tin, gold and lead ores in Bronze Age Britain: The mining, smelting and movement of metal. In A.C. Mair (ed.) Materials and Manufacturing Processes 32 (7-8), Taylor \& Frances on-line [DOI: 10.1080/10426914.2016.1221113]

Timberlake, S. \& Craddock, B.R. 2013. Prehistoric metal mining in Britain: The study of cobble stone mining tools based on artefact study, ethnography and experimentation. Chungara Revista de Antropología Chilena 45, 33-59

Timberlake, S. \& James, D. 2018. A new Early Bronze Age mine site at Cwmystwyth, Ceredigion: archaeological excavations at Penparc (Comet Lode (W)) in 2017. Archaeology in Wales 57-58, 91-100

Timberlake, S. \& Jenkins, D.A. 2001 Prehistoric mining: geochemical evidence from sediment cores at Mynydd Parys, Anglesey. In A. Millard (ed.), Archaeological Sciences '97, Oxford: British Archaeological Reports (International Series) 939, 193-199

Timberlake, S., \& Marshall, P. 2014. The beginnings of metal production in Britain: a new light on the exploitation of ores and the dates of Bronze Age mines. Historical Metallurgy 47(1), 75-92

Tipping, R. 1987. The origins of corroded pollen grains at five early postglacial pollen sites in western Scotland. Review of Palaeobotany \& Palynology 53, 151-61

Tipping, R., Carter, S. and Johnston, D. 1994. Soil pollen and soil micromorphological analyses of old ground surfaces on Biggar Common, Borders Region, Scotland. Journal of Archaeological Science 21(3), 387-401

Tomas, D. 1972. Michael Faraday in Wales. Gwasg Gee

Van Geel, B., Buurman, J., Brinkkemper, O., Schelvis, J., Aptroot, A., van Reenen, G. \& Hakbij1, T. 2003. Environmental reconstruction of a Roman Period settlement site in 
Uitgeest (The Netherlands), with special reference to coprophilous fungi. Journal of Archaeological Science 30, 873-83

Ward, G.K. \& Wilson, S.R. 1978. Procedures for comparing and combining radiocarbon age determinations: a critique. Archaeometry 20(1), 19-32

Williams, R.A. 2019. Boom and bust in Bronze Age Britain: major copper production from the Great Orme mine and European trade c.1600-1400 BC. Antiquity 93 (371), 1178-96

Wilmshurst, J.M. \& McGlone, M.S. 2005a. Corroded pollen and spores as indicators of changing lake sediment sources and catchment disturbance. Journal of Paleolimnology 34(4), 503-17

Wilmshurst, J.M. \& McGlone, M.S. 2005b. Origin of pollen and spores in surface lake sediments: comparison of modern palynomorph assemblages in moss cushions, surface soils and surface lake sediments. Review of Palaeobotany and Palynology 136, 1-15 


\section{APPENDIX I: TABLES}

Table 1: Mynydd Parys radiocarbon results

Dates calibrated using OxCal 4.3.2 (Bronk Ramsey 2009) with Intcal13 calibration curve (Reimer et al. 2013), rounded out to nearest 10 years.

\begin{tabular}{|c|c|c|c|c|c|}
\hline Lab No. & $\begin{array}{c}\text { Radiocarbon } \\
\text { Age (BP) }\end{array}$ & $\begin{array}{l}\delta^{13} \mathrm{C} \\
(\%)\end{array}$ & Context & Material & $\begin{array}{c}95.4 \% \\
\text { probability } \\
\text { (cal BC) }\end{array}$ \\
\hline \multicolumn{6}{|c|}{ Surface spoil (Oxen Quarry, Timberlake 1988) } \\
\hline BM-2584 & $3550 \pm 50$ & -23.9 & Site $3 / 20$ & $\begin{array}{l}\text { Charcoal - mature } \\
\text { oak }\end{array}$ & $2030-1750$ \\
\hline BM-2585 & $3490 \pm 50$ & -25.2 & Site $3 / 13$ & $\begin{array}{l}\text { Charcoal - mature } \\
\text { oak }\end{array}$ & $1940-1680$ \\
\hline BM-2586 & $3500 \pm 50$ & -25.2 & Site $3 \mathrm{~A}$ & $\begin{array}{l}\text { Charcoal - mature } \\
\text { oak }\end{array}$ & $1950-1690$ \\
\hline \multicolumn{6}{|c|}{ Underground spoil (Parys Mine) } \\
\hline BM-3114 & $3540 \pm 40$ & \multicolumn{2}{|c|}{$\begin{array}{l}16 \text { fm (Main } \\
\text { Chamber) } \\
\text { S1.1/105-002 }\end{array}$} & $\begin{array}{l}\text { charcoal } \\
\text { Quercus ssp. }\end{array}$ & $2010-1750$ \\
\hline BM-3115 & $3240 \pm 70$ & \multicolumn{2}{|c|}{$16 \mathrm{fm}$ (North link) $\mathrm{S} 2$} & Coppiced wood & $1690-1320$ \\
\hline BM-3116 & $3600 \pm 70$ & \multicolumn{2}{|c|}{$\begin{array}{l}16 \mathrm{fm} \text { (W of Quarry } \\
\text { Shaft) S4 }\end{array}$} & Branch wood birch & $2150-1750$ \\
\hline Wk-14001 & $3524 \pm 68$ & \multicolumn{2}{|c|}{$\begin{array}{l}\text { S5 via } 20 \mathrm{fm} \text { (Grand } \\
\text { Stope) }\end{array}$} & Coppiced wood & $2040-1680$ \\
\hline Wk-14186 & $3576 \pm 46$ & \multicolumn{2}{|c|}{$\begin{array}{l}16 \text { fm (Main } \\
\text { Chamber) } \\
\text { S1.1/103-016 }\end{array}$} & Branch wood Hazel & $2120-1770$ \\
\hline Wk-14187 & $3499 \pm 43$ & \multicolumn{2}{|c|}{ S1.1/104-005 } & Branch wood Oak & $1940-1690$ \\
\hline Wk-14188 & $3552 \pm 102$ & \multicolumn{2}{|c|}{ S1.1/107-003 } & Branch wood Oak & $2200-1630$ \\
\hline Wk-14189 & $3595 \pm 42$ & \multicolumn{2}{|c|}{ S1.3/307-014 } & $\begin{array}{l}\text { Charcoal Quercus } \\
\text { ssp. }\end{array}$ & $2130-1780$ \\
\hline Wk-14190 & $3514 \pm 44$ & \multicolumn{2}{|c|}{ S1.3/308-015 } & Branch wood Hazel & $1960-1690$ \\
\hline
\end{tabular}


Table 2: Some characteristics of Early Bronze Age mauls from Mynydd Parys

\begin{tabular}{|c|c|c|c|c|c|}
\hline \multicolumn{2}{|c|}{ (a) Properties } & \multirow{2}{*}{$\begin{array}{l}\begin{array}{l}\text { Intact } \\
\text { cobbles }\end{array} \\
66\end{array}$} & \multirow{2}{*}{$\begin{array}{l}\text { Fractured } \\
\text { cobbles } \\
17\end{array}$} & \multirow{2}{*}{$\begin{array}{l}\text { Flakes } \\
35\end{array}$} & \multirow{2}{*}{$\begin{array}{l}\text { Fragments } \\
12\end{array}$} \\
\hline Number & & & & & \\
\hline \multirow[t]{3}{*}{ Weight (g) } & Max-min & $7800-460$ & $4080-210$ & $1630-60$ & 1560-190 \\
\hline & Average & 2050 & 1740 & 750 & 750 \\
\hline & Mode & 1880 & 1500 & 660 & 620 \\
\hline \multirow{4}{*}{$\begin{array}{l}\text { Dimensions } \\
(\mathrm{mm})\end{array}$} & Maximum & $270-40$ & $205-105$ & $190-70$ & $175-80$ \\
\hline & Mode & 140 & 150 & 120 & \\
\hline & Minimum & $140-40$ & $105-20$ & $80-10$ & $80-25$ \\
\hline & Mode & 70 & 70 & 35 & 50 \\
\hline \multicolumn{6}{|c|}{ (b) Petrology } \\
\hline & Silicified siltstone & 2 & - & 1 & 1 \\
\hline & Sandstones & 10 & 2 & 5 & 1 \\
\hline & $\begin{array}{l}\text { Orthoquartzite } \\
\text { (pale buff) }\end{array}$ & 13 & 4 & 2 & 2 \\
\hline & $\begin{array}{l}\text { Orthoquartzite } \\
\text { (Carb.) }\end{array}$ & 2 & 2 & - & - \\
\hline & $\begin{array}{l}\text { Metaquartzite } \\
\text { (Gwna?) }\end{array}$ & 8 & - & - & 1 \\
\hline & Quartz breccia & - & 1 & - & - \\
\hline & Rhyolite/tuff & 4 & 1 & 9 & 3 \\
\hline & Porphyry & 5 & 1 & 3 & 1 \\
\hline & Microgranite & 3 & 3 & 6 & 1 \\
\hline & Microgranodiorite & 2 & 2 & 4 & 1 \\
\hline & Microdiorite & 2 & - & 1 & - \\
\hline & Andesite & 3 & - & - & - \\
\hline & Basalt & 1 & - & - & 1 \\
\hline & Granite & 1 & - & 1 & - \\
\hline & Granite gneiss & 1 & - & - & - \\
\hline & Granodiorite & 2 & - & - & - \\
\hline
\end{tabular}




\begin{tabular}{|l|l|l|l|l|l|}
\hline & Dolerite & 2 & 1 & 2 & - \\
\hline & Meta-tuff & 1 & - & - & - \\
\hline & & & & & \\
\hline (c) Modifications & & $\begin{array}{l}\text { Intact \& } \\
\text { fractured } \\
\text { cobbles }\end{array}$ & Flakes & (Average) \\
\hline Numbers & & 83 & 35 & \\
\hline By use & Flaked & 24 & 12 & \\
\hline & Battered one end & 39 & 15 & \\
\hline & Battered both ends & $20(71 \%)$ & $1(46 \%)$ & $64 \%$ \\
\hline & Battered edge & 15 & 1 & \\
\hline & Battered face (mortar?) & 4 & - & \\
\hline Re-use & battered one end & 18 & 5 & \\
\hline & Battered both ends & $14(35 \%)$ & $1(16 \%)$ & $30 \%$ \\
\hline Adaptation & pecking/rill/notch & $10(12 \%)$ & $3(9 \%)$ & $11 \%$ \\
\hline
\end{tabular}

Table 3: Site S1.1, unit 104 stratigraphy

\begin{tabular}{|c|l|l|}
\hline $\begin{array}{l}\text { Stratigraphic } \\
\text { layers }\end{array}$ & Depth $\mathbf{( c m )}$ & Characteristics \\
\hline 12 & $0-3.2$ & Brown/green clay with charcoal. \\
\hline 11 & $3.2-5$ & Sand yellow coloured clay. \\
\hline 10 & $5-7$ & $\begin{array}{l}\text { Light brown clay with small pieces of quartz and } \\
\text { charcoal. }\end{array}$ \\
\hline 9 & $7-10$ & Light brown/cream clay with quartz. \\
\hline 8 & $10-15$ & $\begin{array}{l}\text { Grey clay, possibly with some organics characterised by } \\
\text { lighter brown bands. Lenses of charcoal are visible. }\end{array}$ \\
\hline 7 & 1515.5 & Dark brown irregular band. Possibly peat. \\
\hline 6 & $15.5-17.5$ & $\begin{array}{l}\text { Dark brown organic substance with clay, charcoal and } \\
\text { quartz. }\end{array}$ \\
\hline 5 & $17.5-22$ & Light grey clay with thin organic? Lens at 20-20.5 cm. \\
\hline 4 & 2226 & Dark grey clay. \\
\hline 3 & $26-27$ & $\begin{array}{l}\text { Very dark grey clay with possible charcoal or decayed } \\
\text { wood. Charcoal at 26.5 cm. }\end{array}$ \\
\hline 2 & 2729 & Light brown/cream clay with quartz. \\
\hline 1 & $29-33$ & Light brown, grey, irregularly laminated clay \\
\hline
\end{tabular}


Table 4: Site S3 stratigraphy.

\begin{tabular}{|c|l|l|}
\hline $\begin{array}{l}\text { Stratigraphic } \\
\text { layers }\end{array}$ & $\begin{array}{l}\text { Depth } \\
\text { (cm) }\end{array}$ & Characteristics \\
\hline 15 & 08 & $\begin{array}{l}\text { Mid-dark grey silt with small charcoal fleck } \\
\text { inclusions and small flecks white-yellow spots } \\
\text { of clay/shale flakes (sub 2mm diameter). }\end{array}$ \\
\hline 14 & $8-18$ & $\begin{array}{l}\text { Mid-dark grey slightly clayey silt, with charcoal } \\
\text { inclusions }\end{array}$ \\
\hline 11 & $18-26$ & $\begin{array}{l}\text { Mid-dark grey clayey silt with small charcoal } \\
\text { fleck inclusions, rotted shale and light clay } \\
\text { pieces and larger shale pieces (5-10mm } \\
\text { diameter) }\end{array}$ \\
\hline $9 \mathrm{~B}$ & $26-30$ & $\begin{array}{l}\text { Light grey-brown silt with light grey/white clay } \\
\text { laminae }\end{array}$ \\
\hline $9 \mathrm{~A}$ & $30-37$ & $\begin{array}{l}\text { Dark grey to mid grey silt with micro laminae } \\
\text { (dark) }\end{array}$ \\
\hline 7 & $37-38$ & $\begin{array}{l}\text { Light grey clay-rich silt speckled with black } \\
\text { charcoal with small shale inclusions }\end{array}$ \\
\hline 5 & $38-43$ & $\begin{array}{l}\text { Light brown clay with yellowish jarosite } \\
\text { inclusion }\end{array}$ \\
\hline 3 & $43-44$ & Dark grey laminated, slightly organic silt \\
\hline 3 & $44-46$ & Dark grey laminated, slightly organic silt \\
\hline 2 & $46-47$ & $\begin{array}{l}\text { Dark grey organic silt with small twigs and } \\
\text { organic matter }\end{array}$ \\
\hline 1 & $47-50$ & Grey clay-rich silt \\
\hline & &
\end{tabular}

\section{Tables 5 and 6}

The nomenclature for Coleoptera (beetles) follows that of Lucht (1987). The right hand Column in Table 5 lists the host plants for the phytophage species of beetle that were recovered and are predominantly derived from Koch $(1989 ; 1992)$. The plant taxonomy follows that of Stace (2010). The affiliation of each beetle species to a particular ecological grouping is indicated in the third column of Table 5. The meaning of each ecological code is explained in the key at the base of Table 5. The occurrence of each of the ecological groupings is expressed as a percentage in Table 6 and is illustrated in Fig. 14. The pasture/ grassland, dung and woodland ecological groupings are calculated as percentages of the number of terrestrial species only, as opposed to the whole fauna. An individual taxon can occur in more than one ecological grouping and, therefore, the proportions presented in Table 6 and Fig. 15 can exceed 100\%. The second column also includes the Red Data Book (rarity) status of the insects recovered. This information, and the codes used are derived from Hyman and Parsons (1992; 1994). The RDB classifications are outlined at the base of the table. 
Table 5. The insects recovered from the material from Mynydd Parys

(Nomenclature follows Lucht, 1987)

\begin{tabular}{|c|c|c|c|c|c|c|c|c|c|c|c|}
\hline \multirow[t]{2}{*}{ Taxa } & \multirow{2}{*}{$\begin{array}{c}\text { Red } \\
\text { data } \\
\text { book } \\
\text { statu } \\
\text { s } \\
\end{array}$} & \multirow{2}{*}{$\begin{array}{l}\text { ecological } \\
\text { code }\end{array}$} & \multirow{2}{*}{$\begin{array}{l}\text { Site } \\
\text { S1 } \\
0- \\
30 \mathrm{~cm}\end{array}$} & \multicolumn{7}{|c|}{ Site $\mathbf{S 3}$} & \multirow{2}{*}{$\begin{array}{l}\text { Phytophage host plants } \\
\text { (based on Koch 1999) }\end{array}$} \\
\hline & & & & $\begin{array}{l}50- \\
46 \mathrm{~cm} \\
\text { (Sub- } \\
\text { units } \\
1-2\end{array}$ & $\begin{array}{l}46- \\
38 \mathrm{~cm} \\
\text { (Sub- } \\
\text { Units } \\
5-3)\end{array}$ & $\begin{array}{l}38- \\
30 \mathrm{~cm} \\
\text { (Sub- } \\
\text { Units } \\
9 \mathrm{~A}-6)\end{array}$ & $\begin{array}{l}30- \\
26 \mathrm{~cm} \\
\text { (Sub- } \\
\text { Unit } \\
9 \mathrm{~B})\end{array}$ & $\begin{array}{l}26- \\
18 \mathrm{~cm} \\
(\text { Sub- } \\
\text { Unit } \\
11)\end{array}$ & $\begin{array}{l}18- \\
8 \mathrm{~cm} \\
\text { (sub- } \\
\text { Unit } \\
14 \text { ) }\end{array}$ & $\begin{array}{l}8- \\
0 \mathrm{~cm} \\
\text { (Sub- } \\
\text { Unit } \\
15)\end{array}$ & \\
\hline \multicolumn{12}{|l|}{ CARABIDAE } \\
\hline Carabus violaceus $\mathrm{L}$. & - & - & - & - & - & - & - & - & 1 & 1 & \\
\hline $\begin{array}{l}\text { Carabus } \\
\text { problematicus Hbst. }\end{array}$ & - & - & - & - & - & - & - & - & 1 & - & \\
\hline $\begin{array}{l}\text { Notiophilus hypocrita } \\
\text { Curt. }\end{array}$ & - & - & - & - & - & 1 & - & - & - & - & \\
\hline Notiophilus spp. & - & - & - & - & - & - & - & - & 3 & 1 & \\
\hline $\begin{array}{l}\text { Trechus } \\
\text { quadristriatus } \\
\text { (Schrk.) }\end{array}$ & - & - & - & - & 1 & - & - & - & - & 1 & \\
\hline $\begin{array}{l}\text { Trechus } \\
\text { quadristriatus } \\
\text { (Schrk.) /T. obtusus } \\
\text { Er. }\end{array}$ & - & ws & 3 & - & - & - & - & - & & & \\
\hline Trechus spp. & - & - & 7 & - & - & 3 & - & 1 & 3 & - & \\
\hline Bembidion spp. & - & - & - & - & - & - & - & 5 & - & 11 & \\
\hline $\begin{array}{l}\text { Trichocellus placidus } \\
\text { (Gyll.) }\end{array}$ & - & ws & - & - & - & - & - & - & - & 8 & \\
\hline $\begin{array}{l}\text { Acupalpus flavicollis } \\
\text { (Sturm.) }\end{array}$ & $\mathrm{Nb}$ & ws & - & - & - & - & - & - & 6 & - & \\
\hline Acupalpus spp. & - & - & - & - & - & - & 1 & 2 & 8 & - & \\
\hline $\begin{array}{l}\text { Pterostichus. diligens } \\
\text { (Sturm.) }\end{array}$ & - & ws & - & - & - & - & - & - & - & 4 & \\
\hline $\begin{array}{l}\text { Pterostichus niger } \\
\text { (Schall.) }\end{array}$ & - & - & - & - & - & - & - & 1 & - & - & \\
\hline $\begin{array}{l}\text { Pterostichus madidus } \\
\text { (F.) }\end{array}$ & - & - & 2 & - & - & - & - & - & - & - & \\
\hline Pterostichus spp. & - & - & 3 & - & - & - & - & 4 & 9 & - & \\
\hline $\begin{array}{l}\text { Calathus } \\
\text { melanocephalus (L.) }\end{array}$ & - & - & - & - & - & - & - & - & - & 4 & \\
\hline Calathus spp. & - & - & 5 & - & - & 2 & - & 4 & - & 7 & \\
\hline Agonum spp. & - & - & 1 & - & - & - & - & - & 7 & 4 & \\
\hline Amara tibialis (Payk.) & - & - & - & - & - & - & - & - & 8 & - & \\
\hline Amara bifrons (Gyll.) & - & - & - & - & - & 1 & - & - & - & - & \\
\hline $\begin{array}{l}\text { Amara equestris } \\
\text { (Duft.) }\end{array}$ & $\mathrm{Nb}$ & - & 1 & - & - & - & - & - & 6 & - & \\
\hline Amara spp. & - & - & 3 & - & - & - & 1 & 2 & 4 & - & \\
\hline \multirow{2}{*}{\multicolumn{12}{|c|}{ DYTISCIDAE }} \\
\hline & & & & & & & & & & & \\
\hline Hydroporus spp. & - & $\mathrm{a}$ & 4 & - & - & - & - & 1 & - & 6 & \\
\hline $\begin{array}{l}\text { Agabus bipustulatus } \\
\text { (L.) }\end{array}$ & - & a & - & - & - & - & - & - & 1 & - & \\
\hline \multicolumn{12}{|l|}{ HYDRAENIDAE } \\
\hline Limnebius spp. & - & $\mathrm{a}$ & - & - & - & 1 & - & 1 & 8 & - & \\
\hline & & & & & & & & & & & \\
\hline \multicolumn{12}{|l|}{ HYDROPHILIDAE } \\
\hline $\begin{array}{l}\text { Cercyon analis } \\
\text { (Payk.) }\end{array}$ & - & df & - & - & - & - & - & - & - & 2 & \\
\hline Cercyon spp. & - & df & - & - & - & - & - & 2 & - & 1 & \\
\hline $\begin{array}{l}\text { Megasternum } \\
\text { boletophagum } \\
\text { (Marsh.) }\end{array}$ & - & df & 2 & - & - & - & - & - & - & - & \\
\hline Megasternum sp. & - & - & - & - & - & - & - & - & - & 1 & \\
\hline $\begin{array}{l}\text { Hydrobius fuscipes } \\
\text { (L.) }\end{array}$ & - & $\mathrm{a}$ & - & - & - & - & - & - & 1 & - & \\
\hline Laccobius spp. & - & $\mathrm{a}$ & - & - & - & - & - & - & 2 & - & \\
\hline \multirow[t]{2}{*}{$\begin{array}{l}\text { Chaetarthria } \\
\text { seminulum (Hbst.) }\end{array}$} & - & $\mathrm{a}$ & - & - & - & - & - & - & 3 & - & \\
\hline & & & - & - & - & - & - & - & - & - & \\
\hline SILPHIDAE & & & & & & & & & & & \\
\hline
\end{tabular}




\begin{tabular}{|c|c|c|c|c|c|c|c|c|c|c|c|}
\hline $\begin{array}{l}\text { Silpha tyrolensis } \\
\text { Laich. }\end{array}$ & - & $\mathrm{g}$ & 1 & - & - & - & - & - & - & - & \\
\hline Silpha sp. & - & - & - & - & - & - & - & - & 1 & - & \\
\hline & & & & & & & & & & & \\
\hline \multicolumn{12}{|l|}{ CATOPIDAE } \\
\hline Choleva spp. & - & - & 7 & - & - & - & - & 4 & 3 & 2 & \\
\hline & & & & & & & & & & & \\
\hline \multicolumn{12}{|l|}{ LIODIDAE } \\
\hline $\begin{array}{l}\text { Agathidium atrum } \\
\text { (Payk.) }\end{array}$ & - & $\mathrm{t}$ & - & - & - & - & 1 & 4 & 2 & - & \\
\hline $\begin{array}{l}\text { Agathidium } \\
\text { sphaerulum Rtt. }\end{array}$ & - & $\mathrm{t}$ & 5 & - & - & - & - & - & 5 & - & \\
\hline Agathidium spp. & - & - & - & - & - & 1 & - & 3 & - & 2 & \\
\hline & & & & & & & & & & & \\
\hline $\begin{array}{l}\text { SCYMINIDAE } \\
\text { Genus and species } \\
\text { Indeterminate }\end{array}$ & & - & 1 & - & - & - & - & 1 & 4 & 4 & \\
\hline & & & & & & & & & & & \\
\hline STAPHYLINIDAE & & & & & & & & & & & \\
\hline $\begin{array}{l}\text { Micropeplus } \\
\text { staphylinoides } \\
\text { (Marsh.) }\end{array}$ & - & df & - & - & - & - & - & 1 & 6 & 2 & \\
\hline $\begin{array}{l}\begin{array}{l}\text { Metopsia gallica } \\
\text { (Koch.) }\end{array} \\
\end{array}$ & - & - & - & - & - & 2 & 1 & - & - & - & \\
\hline Omalium sp. & - & - & 1 & - & - & - & - & - & - & - & \\
\hline $\begin{array}{l}\text { Lathrimaeum } \\
\text { unicolor (Marsh.) }\end{array}$ & - & ws & - & - & - & 1 & 7 & 9 & - & 7 & \\
\hline $\begin{array}{l}\text { Olophrum piceum } \\
\text { (Gyll.) }\end{array}$ & - & ws & - & - & 1 & 1 & - & 2 & 5 & - & \\
\hline $\begin{array}{l}\text { Olophrum fuscus } \\
\text { (Grav.) }\end{array}$ & - & ws & - & - & - & - & - & - & - & 7 & \\
\hline Olophrum spp. & - & ws & 6 & - & - & - & - & - & - & 2 & \\
\hline Acidota crenata (F.) & $\mathrm{Mb}$ & $\mathrm{df}$ & - & - & - & - & - & 1 & - & 2 & \\
\hline $\begin{array}{l}\text { Lesteva longelytrata } \\
\text { (Goeze) }\end{array}$ & - & ws & - & - & - & - & - & - & 2 & - & \\
\hline Lesteva sp. & - & ws & - & - & - & - & - & 1 & - & - & \\
\hline Stenus spp. & - & - & - & - & - & - & - & 2 & 4 & 5 & \\
\hline Lathrobium spp. & - & - & - & - & - & - & - & - & 1 & 3 & \\
\hline $\begin{array}{l}\text { Xantholinus linearis } \\
\text { (Ol.) }\end{array}$ & - & - & - & - & - & - & - & - & 13 & - & \\
\hline Xantholinus spp. & - & - & - & - & 1 & 2 & - & 4 & - & 4 & \\
\hline Philonthus spp. & - & - & - & - & - & - & - & - & 11 & - & \\
\hline Staphylinus spp. & - & - & - & - & - & - & - & - & 3 & 4 & \\
\hline Quedius sp. & - & - & - & - & - & - & - & 1 & - & - & \\
\hline Tachyporus spp. & - & - & - & - & - & - & - & - & 14 & 7 & \\
\hline & & & & & & & & & & & \\
\hline PSELAPHIDAE & & & & & & & & & & - & \\
\hline $\begin{array}{l}\text { Bryaxis bulbifer } \\
\text { (Riechb.) }\end{array}$ & - & - & - & - & - & 1 & - & - & 5 & - & \\
\hline & & & & & & & & & & & \\
\hline \multicolumn{12}{|l|}{ ELATERIDAE } \\
\hline Agriotes sp. & - & $p$ & - & - & - & - & - & - & - & 1 & \\
\hline \multicolumn{12}{|l|}{ HELODIDAE } \\
\hline Cyphon spp. & - & ws & 1 & - & - & 4 & - & 1 & 2 & - & \\
\hline & & & & & & & & & & & \\
\hline \multicolumn{12}{|l|}{ NITIDULIDAE } \\
\hline Meligethes sp. & - & $\mathrm{p}$ & - & - & - & - & - & - & - & 1 & \\
\hline \multirow{2}{*}{\multicolumn{12}{|c|}{ LATHRIDIIDAE }} \\
\hline & & & & & & & & & & & \\
\hline $\begin{array}{l}\text { Enicmus minutus } \\
\text { (Group) }\end{array}$ & - & - & - & - & - & - & - & - & 1 & - & \\
\hline $\begin{array}{l}\text { Corticaria or } \\
\text { Corticarina spp. }\end{array}$ & - & - & - & - & - & - & - & - & 2 & - & \\
\hline & & & & & & & & & & & \\
\hline TENEBRIONIDAE & & & & & & & & & & & - \\
\hline $\begin{array}{l}\text { Cylindronotus } \\
\text { laevioctostriatus } \\
\text { (Goeze.) }\end{array}$ & & $\mathrm{t}$ & 2 & - & - & - & - & 2 & 2 & 3 & $\begin{array}{l}\text { Calluna spp. (heather), } \\
\text { under bark and in deadwood } \\
\text { of a range of trees }\end{array}$ \\
\hline \multirow{2}{*}{\multicolumn{12}{|c|}{ SCARABAEIDAE }} \\
\hline & & & & & & & & & & & \\
\hline Geotrupes spp. & - & $\mathrm{df}$ & 5 & - & - & - & - & - & - & - & \\
\hline Aphodius spp. & & $\mathrm{df}$ & - & - & - & - & - & - & 2 & - & \\
\hline & & & & & & & & & & & \\
\hline CHRYSOMELIDAE & & & & & & & & & & & \\
\hline
\end{tabular}




\begin{tabular}{|c|c|c|c|c|c|c|c|c|c|c|c|}
\hline Phyllotreta spp. & - & $p$ & 1 & 1 & - & - & - & - & - & - & \\
\hline Haltica spp. & - & $\mathrm{t}$ & 1 & - & - & - & - & 1 & - & - & \\
\hline $\begin{array}{l}\text { Chaetocnema } \\
\text { concinna (Marsh.) }\end{array}$ & - & $\mathrm{p}$ & - & - & - & 1 & - & - & - & - & \\
\hline & & & & & & & & & & & \\
\hline SCOLYTIDAE & - & & & & & & & & & & \\
\hline $\begin{array}{l}\text { Dryocoetes villosus } \\
\text { (F.) }\end{array}$ & - & $\mathrm{t}$ & - & - & - & 2 & - & - & - & - & $\begin{array}{l}\text { Under bark of a range of } \\
\text { deciduous trees }\end{array}$ \\
\hline & & & & & & & & & & & \\
\hline \multicolumn{12}{|l|}{ CURCULIONIDAE } \\
\hline $\begin{array}{l}\text { Apion frumentarium } \\
\text { (Payk.) }\end{array}$ & $\mathrm{Nb}$ & $\mathrm{p}$ & - & 1 & - & - & - & 6 & 3 & 1 & On Rumex spp. (dock) \\
\hline Apion spp. & - & $\mathrm{p}$ & 6 & - & - & - & 1 & 1 & - & 5 & \\
\hline Polydrusus sp. & - & $\mathrm{p}$ & - & - & - & - & - & - & - & 1 & \\
\hline Phyllobius spp. & - & $\mathrm{t}$ & - & - & 1 & - & - & - & 5 & - & \\
\hline $\begin{array}{l}\text { Trachyphloeus } \\
\text { alternans Gyll. }\end{array}$ & $\mathrm{Nb}$ & $\mathrm{p}$ & - & - & - & - & 1 & 1 & 3 & 7 & $\begin{array}{l}\text { Often associate with } \\
\text { Helianthemum } \\
\text { nummularinum (L.) Mill. } \\
\text { (rock-rose) or Plantago spp. } \\
\text { (plantains) }\end{array}$ \\
\hline Trachyphloeus spp. & - & - & - & - & - & 1 & - & 1 & - & - & \\
\hline Barypeithes spp. & - & - & 4 & - & - & - & - & 3 & 4 & 7 & \\
\hline $\begin{array}{l}\text { Strophosoma } \\
\text { capitatum (Geer.) }\end{array}$ & - & $\mathrm{t}$ & - & - & - & - & - & - & - & 1 & \\
\hline $\begin{array}{l}\text { Sitona } \\
\text { regensteinensis } \\
\text { (Hbst.) }\end{array}$ & - & $\mathrm{p}$ & - & - & - & 1 & - & - & - & - & $\begin{array}{l}\text { Cytisus scoparius (L.) Link } \\
\text { (broom) or Ulex europaeus } \\
\text { L. (gorse) }\end{array}$ \\
\hline Sitona hispidulus (F.) & - & $\mathrm{p}$ & 1 & - & - & 1 & - & 2 & 8 & 1 & $\begin{array}{l}\text { Trifolium L. (clover), } \\
\text { FABACEAE (Pea Family) }\end{array}$ \\
\hline $\begin{array}{l}\text { Sitona cylindricollis } \\
\text { (Fahrs.) }\end{array}$ & - & $\mathrm{p}$ & 3 & - & - & - & - & - & - & 3 & Melilotus spp. (melilot) \\
\hline Sitona spp. & - & - & 5 & - & - & - & - & 3 & 6 & 5 & \\
\hline $\begin{array}{l}\text { Alophus triguttatus } \\
\text { (F.) }\end{array}$ & $\mathrm{Nb}$ & $\mathrm{p}$ & - & - & - & - & - & 1 & - & - & $\begin{array}{l}\text { Plantago lanceolata } \mathrm{L} \text {. } \\
\text { (ribwort plantain) }\end{array}$ \\
\hline Hypera spp. & - & - & - & - & - & - & - & 2 & 1 & 3 & \\
\hline Ceutorhynchus spp. & - & - & - & - & - & - & - & 2 & - & - & \\
\hline $\begin{array}{l}\text { Micrelus ericae } \\
\text { (Gyll.) }\end{array}$ & - & $\mathrm{m}$ & - & - & 1 & - & - & - & - & 2 & $\begin{array}{l}\text { Calluna vulgaris (L.) Hull } \\
\text { (heather), Erica tetralix } \mathrm{L} . \\
\text { (crossed leaved Heather) }\end{array}$ \\
\hline Gymnetron spp. & - & $\mathrm{p}$ & 1 & - & - & - & 1 & 3 & - & 2 & $\begin{array}{l}\text { Plantago lanceolata } \mathrm{L} . \\
\text { (ribwort plantain), Plantago } \\
\text { spp. (plantains) }\end{array}$ \\
\hline
\end{tabular}

Key to ecological groupings used

$\mathrm{a}=$ aquatic water beetles

ws = waterside taxa often associated with emergent vegetation

df $=$ taxa often associated with dung

$\mathrm{g}=$ taxa often associated with grassland/pasture

$\mathrm{p}=$ taxa associated with grassland and open areas

$\mathrm{t}=$ taxa associated with dead wood, fallen timber and tree leaf

$\mathrm{m}=$ taxa associated with moorland
Red Data Book status (Hyman and Parsons 1994)

RDB1 = Endangered

RDB2 $=$ Vulnerable

RDB3 = Rare

RDBK = Status not sufficiently known

RDBX = presumed extinct in the British Isles

$\mathrm{NA}$ and $\mathrm{NB}=$ notable species

Table 6. The proportions of the ecological groups of Coleoptera from Mynydd Parys

\begin{tabular}{|c|c|c|c|c|c|c|c|c|}
\hline & \multirow{2}{*}{$\begin{array}{l}\text { Site S1 } \\
\begin{array}{l}0-30 \\
\mathrm{~cm}\end{array}\end{array}$} & \multicolumn{7}{|l|}{ Site S3 } \\
\hline & & $\begin{array}{l}50-46 \mathrm{~cm} \\
\text { (Sub-units } \\
1-2)\end{array}$ & $\begin{array}{l}46-38 \mathrm{~cm} \\
\text { (Sub-units } \\
3-5 \text { ) }\end{array}$ & $\begin{array}{l}38-30 \mathrm{~cm} \\
\text { (Sub-units } \\
\text { 6-9A) }\end{array}$ & $\begin{array}{l}30-26 \mathrm{~cm} \\
\text { (Sub-unit } \\
9 B)\end{array}$ & $\begin{array}{l}26-18 \mathrm{~cm} \\
\text { (Sub-unit } \\
11 \text { ) }\end{array}$ & $\begin{array}{l}18-8 \\
\text { cm } \\
\text { (Sub- } \\
\text { unit 14) }\end{array}$ & $\begin{array}{l}8-0 \mathrm{~cm} \\
\text { (Sub- } \\
\text { unit 15) }\end{array}$ \\
\hline Minimum Number of Individuals & 82 & 2 & 5 & 26 & 14 & 85 & 189 & 145 \\
\hline Minimum Number of Taxa & 26 & 2 & 5 & 16 & 8 & 34 & 41 & 41 \\
\hline$\%$ Aquatic (a) & $4.9 \%$ & $0.0 \%$ & $0.0 \%$ & $3.8 \%$ & $0.0 \%$ & $2.4 \%$ & $7.9 \%$ & $4.1 \%$ \\
\hline$\%$ Waterside (ws) & $18.3 \%$ & $0.0 \%$ & $20.0 \%$ & $23.1 \%$ & $57.1 \%$ & $20.0 \%$ & $11.6 \%$ & $19.3 \%$ \\
\hline \% Dung/ Foul Matter (df) & $11.1 \%$ & $0.0 \%$ & $0.0 \%$ & $0.0 \%$ & $0.0 \%$ & $6.1 \%$ & $5.3 \%$ & $6.3 \%$ \\
\hline \% Grassland (p) & $20.6 \%$ & $100.0 \%$ & $0.0 \%$ & $15.8 \%$ & $50.0 \%$ & $21.2 \%$ & $9.2 \%$ & $19.8 \%$ \\
\hline$\%$ Trees/ Woodland (t ) & $12.7 \%$ & $0.0 \%$ & $25.0 \%$ & $10.5 \%$ & $16.7 \%$ & $10.6 \%$ & $9.2 \%$ & $3.6 \%$ \\
\hline \% Moorland (m) & $0.0 \%$ & $0.0 \%$ & $25.0 \%$ & $0.0 \%$ & $0.0 \%$ & $0.0 \%$ & $0.0 \%$ & $1.8 \%$ \\
\hline
\end{tabular}


Table 7: Plant macrofossils - Site S1.1

\begin{tabular}{|c|c|c|c|c|c|c|c|c|c|c|c|c|}
\hline \multicolumn{2}{|l|}{ Section } & 1.1 & 1.1 & 1.1 & 1.1 & 1.1 & 1.1 & 1.1 & 1.1 & 1.1 & 1.1 & 1.1 \\
\hline \multicolumn{2}{|l|}{ Context } & 101 & 104 & 104 & 104 & 104 & 104 & 104 & 104 & 104 & 104 & 105 \\
\hline \multicolumn{2}{|l|}{ Unit } & Top & $12+$ & $10+9$ & 8 & $6+7$ & 5 & 4 & 3 & 2 & 1 & \\
\hline \multicolumn{2}{|l|}{ Volume processed (ml) } & 100 & 100 & 100 & 100 & 100 & 100 & 100 & 100 & 100 & 100 & 100 \\
\hline \multicolumn{2}{|l|}{ Bud scales } & - & $(+)$ & + & - & + & + & $(+)$ & $(+)$ & - & + & $(+)$ \\
\hline \multicolumn{2}{|l|}{ Charcoal } & + & - & - & +++ & - & - & - & +++ & ++ & +++ & + \\
\hline \multicolumn{2}{|l|}{ Insect / beetle } & - & $(+)$ & + & $(+)$ & + & + & + & + & $(+)$ & + & - \\
\hline \multicolumn{13}{|l|}{ Waterlogged remains (total count) } \\
\hline \multicolumn{2}{|l|}{ (g) Leontodon sp (Hawkbit) } & - & - & - & - & - & - & - & 1 & - & - & - \\
\hline \multirow{2}{*}{\multicolumn{2}{|c|}{ (q) Chara sp (Stoneworts) }} & - & - & - & - & - & - & - & 1 & - & - & - \\
\hline & seed & - & - & 1 & - & 3 & 1 & - & 1 & - & 1 & - \\
\hline \multicolumn{2}{|l|}{ (r) Persicaria lapathifolia (Pale Persicaria) } & - & - & - & - & - & 1 & - & - & - & - & - \\
\hline \multicolumn{2}{|l|}{ (r) Plantago major (Greater Plantain) } & - & - & - & - & - & 1 & - & - & - & - & - \\
\hline \multicolumn{2}{|l|}{ (r) Urtica dioica (Common Nettle) } & - & - & 1 & 3 & 2 & 2 & 2 & - & - & 1 & - \\
\hline \multicolumn{2}{|l|}{ (t) Betula sp (Birches) } & - & - & - & 1 & 1 & - & - & - & - & - & - \\
\hline \multicolumn{2}{|l|}{ (t) Rubus sp (Brambles) } & - & - & - & - & 1 & - & - & - & - & 3 & - \\
\hline \multicolumn{2}{|l|}{ (t) Rubus fruticosus agg. (Bramble) } & - & - & - & - & 1 & - & - & - & - & 1 & 2 \\
\hline \multicolumn{2}{|l|}{ (t) Rubus idaeus (Wild Raspberry) } & - & - & - & - & 1 & - & - & - & - & - & - \\
\hline \multicolumn{2}{|l|}{ (w) Carex sp (Sedges) } & - & - & - & - & 4 & 1 & - & - & - & 2 & - \\
\hline \multicolumn{2}{|l|}{ (w) Juncus sp (Rushes) } & 9 & 36 & 20 & 9 & 9 & 9 & 2 & 3 & 5 & 17 & 21 \\
\hline (w) Juncus articulatus type (Jointed Rush type) & seed & - & - & - & - & 1 & 1 & - & - & 2 & 4 & - \\
\hline (w) Juncus effusus type (Soft-rush type) & seed & - & 3 & 15 & 43 & 72 & 26 & 12 & 16 & 18 & 15 & 14 \\
\hline \multicolumn{2}{|l|}{ (w) Rorippa sp (Yellow-cresses) } & - & - & 1 & 2 & 3 & 2 & - & 3 & - & 10 & - \\
\hline $\begin{array}{l}\text { (w) Schoenoplectus lacustris (Common Club- } \\
\text { rush) }\end{array}$ & nutlet & - & 1 & - & - & - & - & - & - & - & - & - \\
\hline (w) Sphagnum sp (Sphagnum moss) & leaf & - & - & 1 & 3 & 13 & 7 & 1 & - & - & 3 & 1 \\
\hline (w) Sphagnum sect. Acutifolia (Sphagnum moss) & leaf & - & 66 & - & - & 1 & - & - & - & - & - & - \\
\hline (w) Typha sp (Bulrush) & seed & - & - & - & - & 1 & - & - & - & - & - & - \\
\hline (x) Brassicaceae undiff. (Cabbage family) & seed & - & - & - & - & 2 & - & - & - & - & - & - \\
\hline (x) Caryophyllaceae undiff. (Pink family) & seed & - & 1 & - & 4 & 4 & 2 & 3 & 3 & 2 & 3 & - \\
\hline (x) Cenococcum geophilum (Soil fungus) & sclerotia & 10 & 55 & 23 & 30 & 35 & 13 & 8 & 12 & 4 & 12 & 7 \\
\hline (x) Chenopodium sp (Goosefoots) & seed & - & - & 1 & - & - & - & - & 1 & - & - & - \\
\hline (x) Hypericum sp (St John's-worts) & seed & - & - & 1 & - & 1 & 1 & 1 & 1 & - & - & - \\
\hline (x) Musci sp (Mosses excluding Sphagnum) & branch & - & 12 & 3 & 52 & $>200$ & 51 & 8 & 12 & 19 & 32 & - \\
\hline (x) Potentilla sp (Cinquefoils) & achene & - & - & - & 1 & - & - & - & - & - & - & - \\
\hline (x) Poaceae undiff. (Grass family) & caryopsis & 1 & 11 & 3 & 21 & 16 & 11 & 8 & 17 & 6 & 35 & - \\
\hline (x) Prunella vulgaris (Selfheal) & nutlet & - & - & - & - & - & 1 & - & 1 & - & - & - \\
\hline (x) Pteridium aquilinum (Bracken) & nent & - & - & 11 & 25 & $>200$ & 4 & 3 & 11 & 2 & 5 & - \\
\hline (x) Pteridium aquilinum (Bracken) & (with spores) & - & 97 & - & 248 & 408 & - & - & 166 & 31 & - & - \\
\hline (x) Pteridophyta undiff. (Ferns) & sporangium & - & - & 60 & - & - & 114 & 90 & - & - & 63 & 30 \\
\hline (x) Ranunculus subgenus Ranunculus (Buttercup) & achene & - & - & - & - & - & 1 & - & - & - & - & - \\
\hline
\end{tabular}

[g-grassland; q-aquatic; r-ruderal; t-tree/woodland; w-wet/damp ground; $x$-wide niche.

(+): trace; +: rare; ++: occasional; +++: common; ++++: abundant]

Table 8: Plant macrofossils - Sections S1.2 and S1.3

\begin{tabular}{|c|c|c|c|c|c|c|c|}
\hline Section & & 1.2 & 1.2 & 1.2 & 1.2 & 1.3 & 1.3 \\
\hline Context & & 207 & 204 & 204 & 204 & 307 & 308 \\
\hline Unit & & A & B & $\mathbf{C}$ & D & A & B \\
\hline Volume processed $(\mathrm{ml})$ & & 100 & 100 & 100 & 100 & 100 & 100 \\
\hline Bud scales & & - & $(+)$ & - & - & - & - \\
\hline Charcoal & & + & +++ & ++ & +++ & $(+)$ & +++ \\
\hline Insect / beetle & & - & - & - & $(+)$ & - & + \\
\hline \multicolumn{8}{|l|}{ Waterlogged remains (total count) } \\
\hline (r) Cerastium sp (Mouse-ears) & seed & \multirow{10}{*}{$\begin{array}{l}- \\
- \\
1 \\
- \\
- \\
11 \\
- \\
8 \\
- \\
4\end{array}$} & \multirow{10}{*}{$\begin{array}{l}- \\
- \\
- \\
- \\
- \\
5 \\
- \\
- \\
- \\
1\end{array}$} & \multirow{10}{*}{$\begin{array}{l}- \\
- \\
- \\
- \\
- \\
8 \\
- \\
- \\
- \\
-\end{array}$} & \multirow{10}{*}{$\begin{array}{l}- \\
- \\
- \\
1 \\
1 \\
16 \\
1 \\
20 \\
2 \\
9\end{array}$} & \multirow{10}{*}{$\begin{array}{l}- \\
- \\
- \\
- \\
- \\
7 \\
- \\
- \\
- \\
-\end{array}$} & \multirow{5}{*}{$\begin{array}{l}1 \\
1 \\
3 \\
1 \\
-\end{array}$} \\
\hline (r) Plantago major (Greater Plantain) & seed & & & & & & \\
\hline (r) Urtica dioica (Common Nettle) & achene & & & & & & \\
\hline (t) Rubus sp (Brambles) & fruitstone & & & & & & \\
\hline (w) Carex sp (Sedges) & trigonous nutlet & & & & & & \\
\hline (w) Juncus sp (Rushes) & seed & & & & & & 10 \\
\hline (w) Juncus articulatus type (Jointed Rush type) & seed & & & & & & - \\
\hline (w) Juncus effusus type (Soft-rush type) & seed & & & & & & 59 \\
\hline (w) Rorippa sp (Yellow-cresses) & seed & & & & & & 3 \\
\hline (w) Sphagnum sp (Sphagnum moss) & leaf & & & & & & 2 \\
\hline
\end{tabular}




\begin{tabular}{|c|c|c|c|c|c|c|c|}
\hline (w) Typha sp (Bulrush) & seed & - & 2 & - & 1 & - & 1 \\
\hline (x) Brassicaceae undiff. (Cabbage family) & seed & - & - & - & - & - & 1 \\
\hline (x) Cenococcum geophilum (Soil fungus) & sclerotia & 16 & 12 & 3 & 8 & 3 & 45 \\
\hline (x) Chenopodium sp (Goosefoots) & seed & - & - & - & - & - & 1 \\
\hline (x) Musci sp (Mosses excluding Sphagnum) & branch & - & 4 & - & 22 & - & 26 \\
\hline (x) Potentilla sp (Cinquefoils) & achene & - & 1 & - & - & - & 1 \\
\hline (x) Poaceae undiff. (Grass family) & caryopsis & 1 & 1 & 2 & 2 & - & 6 \\
\hline (x) Pteridium aquilinum (Bracken) & frond fragment & - & 3 & 1 & 3 & - & 5 \\
\hline (x) Pteridium aquilinum (Bracken) & sporangium (with spores) & 7 & - & - & 168 & - & 179 \\
\hline (x) Pteridophyta undiff. (Ferns) & sporangium & - & 20 & - & - & - & - \\
\hline
\end{tabular}

[r-ruderal; t-tree/woodland; w-wet/damp ground; $\mathrm{x}$-wide niche.

$(+)$ : trace; +: rare; ++: occasional; +++: common; ++++: abundant]

Table 9: Plant macrofossils - Section S3

\begin{tabular}{|c|c|c|c|}
\hline Section & & 3 & 3 \\
\hline Depth $(\mathrm{cm})$ from the top & & 0-30 & 30-52 \\
\hline Volume processed $(\mathrm{ml})$ & & 200 & 200 \\
\hline Ericaceae undiff. (Heathers) & leaves & +++ & +++ \\
\hline Insect / beetle & & +++ & $(+)$ \\
\hline \multicolumn{4}{|l|}{ Waterlogged remains (total count) } \\
\hline (g) Leontodon sp (Hawkbit) & achene & \multirow{9}{*}{$\begin{array}{l}3 \\
2591 \\
- \\
1 \\
- \\
2 \\
1 \\
1 \\
>2000\end{array}$} & \multirow{9}{*}{$\begin{array}{l}- \\
36 \\
1 \\
- \\
3 \\
- \\
- \\
- \\
804\end{array}$} \\
\hline (q) Callitriche sp (Water-starwort) & fruit & & \\
\hline (q) Lemna sp (Duckweeds) & fruit & & \\
\hline (r) Aphanes sp (Parsley-pierts) & seed & & \\
\hline (t) Betula $\mathrm{sp}$ (Birches) & fruit & & \\
\hline (t) Rubus sp (Brambles) & fruitstone & & \\
\hline (t) Rubus idaeus (Wild Raspberry) & fruitstone & & \\
\hline (w) Cyperaceae undiff. (Sedge family) & trigonous nutlet & & \\
\hline (w) Juncus sp (Rushes) & seed & & \\
\hline $\begin{array}{l}\text { (w) Juncus articulatus type (Jointed Rush } \\
\text { type) }\end{array}$ & seed & 15 & 5 \\
\hline (w) Juncus effusus type (Soft-rush type) & seed & $>2000$ & 548 \\
\hline (w) Rorippa sp (Yellow-cresses) & seed & 259 & 43 \\
\hline (w) Sphagnum papillosum (Sphagnum moss) & branch & 1 & - \\
\hline (x) Brassicaceae undiff. (Cabbage family) & seed & - & 1 \\
\hline (x) Cenococcum geophilum (Soil fungus) & sclerotia & 51 & 82 \\
\hline (x) Hypericum sp (St John's-worts) & seed & 1 & - \\
\hline (x) Lamiaceae undiff. (Dead-nettle family) & nutlet & - & 1 \\
\hline (x) Musci sp (Mosses excluding Sphagnum) & branch & 20 & - \\
\hline (x) Potentilla sp (Cinquefoils) & achene & 11 & - \\
\hline (x) Poaceae undiff. (Grass family) & caryopsis & 1 & - \\
\hline (x) Pteridophyta undiff. (Ferns) & sporangium & 10 & 9 \\
\hline (x) Rumex sp (Docks) & nutlet & 1 & - \\
\hline (x) Saxifraga sp (Saxifrages) & seed & 2 & - \\
\hline (x) Viola sp (Violets) & seed & 2 & - \\
\hline
\end{tabular}

[g-grassland; q-aquatic; r-ruderal; t-tree/woodland; w-wet/damp ground; $\mathrm{x}$-wide niche.

(+): trace; +: rare; ++: occasional; +++: common; ++++: abundant] 


\section{APPENDIX II: PALAEOENVIRONMENTAL DATA}

\section{Introduction}

Palaeoenvironmental data collected from mine spoil heaps, gallery floors and sediments that accumulate in mines and adits during and after the cessation of activities can all feasibly preserve evidence of human-environment interactions in the mining landscape including resource-based aspects of mining, such as firesetting and the use of wood fuel, and vegetational changes such as the depletion of local woodland, as well as generating a pollution signal (Burnham et al. 1992; Mighall \& Chambers 1993; Mighall et al. 2000; 2002a and b, 2009, 2017).

Sediments from S1.1 and S3 were targeted for analysis. A monolith was cut from context (hereafter referred to as 'unit') 104 (Fig. 5; Table 3), which has been radiocarbon-dated to $3499 \pm 43$ BP (1940-1690 cal BC; Table 1) that appear to confirm that the sediments are of prehistoric age. Additional bulk samples were obtained from units 101, 105, 204, 207307 and 308 for plant macrofossil analysis. The latter two units have radiocarbon dates of 3595 $\pm 42(307 ; 2130-1780 \mathrm{cal} \mathrm{BC})$ and $3514 \pm 44(308 ; 1960-1690 \mathrm{cal} \mathrm{BC})$ placing them into the Bronze Age. A second monolith was taken from S3 (Fig. 5; Table 4).

A stratigraphic description of both monoliths is provided in Tables 3 and 4. Each sedimentary layer was assigned a sub-unit number and a sample from each sub-unit was analysed for pollen using the procedure described by Barber (1976), incorporating a density flotation procedure (Nakagawa et al. 1998). Three hundred land pollen grains were counted for each sub-sample. Pollen was identified with the aid of keys (Fægri et al. 1989; Moore et al. 1991; Andrew 1984), photographs (Reille 1992) and reference to a modern type slide collection. The results of the pollen analysis are shown in Figs 10 and 11. The data are expressed as percentages of total land pollen (TLP).

Insect samples were processed at the Department of Classics, Ancient History and Archaeology (University of Birmingham) using the standard method of paraffin flotation as outlined in Kenward et al. (1980). Insect remains were sorted and identified under a lowpower binocular microscope at magnifications between $\mathrm{x} 15-\mathrm{x} 45$. Where achievable, the insect remains were identified to species level by direct comparison to specimens in the Gorham and Girling Insect Collections housed at the University of Birmingham. The majority of the insect fauna recovered were Coleoptera (beetles) with a few Hemiptera (true bugs) and Diptera (flies) present. A list of the insects recovered is presented in Table 5. In order to aid interpretation, where possible, taxa have been assigned to ecological groupings, 
following a simplified version of the scheme suggested by Robinson (1981, 1983; Table 5, column 3).

Sub-samples of sediment were disaggregated in cold water and washed through a nest of sieves ranging from $150-500 \mu \mathrm{m}$ to extract plant macrofossils. The 17 sub-samples from Site S1.1 were $100 \mathrm{ml}$ in volume, while the two from Site $S 3(0-30 \mathrm{~cm}$ and $30-52 \mathrm{~cm})$ were $200 \mathrm{ml}$. The wet residues were scanned for botanical remains at up to x60 magnification using a Leica MZ7.5 stereomicroscope. Fern sporangia were examined at up to x600 magnification to look for diagnostic spores. Identifications were undertaken by comparison with modern reference material. Plant nomenclature follows Stace (2010). Habitat classifications follow Preston et al. (2002). Results are presented in Tables 7, 8 and 9.

\section{Sites S1 .1, 1.2, 1.3, Unit 104 (Fig. 10; Table 5, 7, 8 and 9)}

Twelve samples were analysed from 11 stratigraphic sub-units for microfossils. Two samples were analysed from sub-unit 8 , whilst sub-unit 11 contained no pollen. The pollen diagram is characterised by the regular occurrence of tree and shrub pollen. Corylus avellana-type is well represented along with Quercus, Betula and Alnus. Pinus, Ulmus, Tilia and Fraxinus are recorded sporadically in trace amounts. Notwithstanding the taphonomic processes that have led to the accumulation of these sediments, these data suggest the presence of a mixed deciduous woodland locally. This woodland contains taxa (such as oak and hazel) commonly used in prehistoric mines, for example, firesetting (Timberlake 2003). The total percentage of tree and shrub pollen suffers a short-lived decline in the lowest sample of sub-unit 5, and selective declines in Quercus occur between sub-units 5 and 6 and from sub-unit 7 to 8 . Corylus avellana-type percentages decrease between sub-units 6 and 7 and sub-units 10 and 11 (along with Alnus). These declines may well be the result of demand for timber and wood by the miners. They are typical of the small-scale, temporary decreases in woodland taxa reconstructed in pollen diagrams close to prehistoric mining and metalworking sites (e.g. Mighall and Chambers 1993; Mighall et al. 2000).

Evidence for trees and shrubs in the plant macrofossil record from S1.1, S1.2 and S1.3 is limited to a few remains of Betula (birch), Rubus (brambles and raspberry), indeterminate bud scales, and sclerotia of the soil fungus Cenococcum geophilum. The latter is an ectomycorrhizal species commonly found in soils of scrub and woodland and has mutualistic associations with certain trees, particularly members of the Betulaceae (birch, alder and hazel), Fagaceae (oak) and Pinaceae (pine) families (Hudson 1986). Charcoal remains are common in six of the S1 samples, reflecting availability of wood fuel. 
The insect fauna from S1.1 is moderately sized, fairly diverse and dominated by a range of beetles (Coleoptera). This includes a limited number of taxa associated with woodland: Agathidum sphaerulum, which is associated with rotting wood and timbers, and Cylindronotus laevioctostriatus, which is found under the bark or in the rotting wood of oak, beech and in the decayed stumps of heather. The members of the Haltica genus are normally associated with willow or heather.

Wet, acidic grasslands were also part of the mosaic of vegetation in and around Mynydd Parys. Poaceae percentages are well represented in each sub-unit, with a suite of herbaceous pollen taxa present in low percentages throughout the S1.1 sedimentary sequence including Cyperaceae, Caryophyllaceae, Apiaceae and Succisa, indicative of fen/marsh (Brown et al. 2007). This is supported by the plant macrofossil record from S1.1, S1.2 and S1.3 which comprise a broadly similar range of plant remains, largely deriving from open grassland and wetland habitats. Damp ground communities with Juncus sp (rushes), Carex sp (sedges) and Rorippa sp (yellow-cress) are represented, with low occurrences of Sphagnum leaves reflecting mire vegetation. A single oosporangium of the submerged aquatic Chara $\mathrm{sp}$ (stonewort), coupled with rare records of emergents Typha sp (bulrush) and Schoenoplectus lacustris (common club-rush), and the trace occurrence of Potamogeton natans-type pollen, indicates the presence of plant species associated with small pools of standing water.

Damp open grassland, meadow and/or grazed pasture are additional features of the landscape, as reflected by plant macrofossil records of Poaceae (grasses), Leontodon sp (hawkbits), Cerastium sp (mouse-ears), Potentilla sp (cinquefoils), Prunella vulgaris (selfheal) and Ranunculus sp (buttercups). Ruderals including Persicaria lapathifolia (pale persicaria) and Plantago major (greater plantain) would have favoured open disturbed habitats, with Chenopodium sp (goosefoots) and Urtica dioica (common nettle) indicating areas of relatively nutrient-rich soils.

A noticeable peak in Ranunculaceae, Potentilla-type and Plantago lanceolata, that are indicative of disturbed ground and pasture, is also observed in the lowest sample from sub unit 5 in the S1.1 pollen record, and coincides with the decrease in the percentage of tree and shrub pollen. Changes in the percentages of these taxa and the presence of others, including Lactuceae, Rumex sp. and Polygonum aviculare-type, and the occurrence of coprophilous dung fungi, Tripterospora-type (HdV-169A) and Podospora-type (HdV-368) (van Geel et al. 2003), suggest that humans were exploiting local grasslands, possibly for grazing. Calluna also exceeds 5\% (of total land pollen) and this may well be derived from heather that still colonises the spoil deposited on Mynydd Parys today. 
Bracken, a fern of moorland and hill pasture, is represented in most of the samples by both sporangia and frond fragments, and would have been well suited to the acidic soil conditions of the site. Notably large numbers of bracken (and moss) remains are present in context 104 (sub-unit $6 \&$ 7; Table 7), the most species diverse sample from Site S1.1. Bracken may have provided a useful resource to former inhabitants of the site, as the dry, brown fronds in autumn make a good fuel and fresh fronds were useful for packing and flooring material (Gale \& Cutler 2000).

The beetle fauna also contains a number of taxa that are associated with species of plants from open areas, grassland or disturbed ground (group ' $g$ ' in Table 5 and Fig. 14) consistent with the pollen evidence. Typical of these taxa are Apion spp., Sitona hispidulus (associated with melilots - Melilotus spp.), Sitona cylindricollis (associated with clover - Trifolium spp.) and Gymnetron spp. (associated with plantains - Plantago spp.). The 'dor beetle' Geotrupes spp. is usually associated with animal dung in heathland, rough grassland and sandy areas (Jessop 1986). Most species of Choleva and Barypeithes are found associated with the roots of grass and mossy areas. Many of the Carabidae 'ground beetle' recovered, such as Trechus quadristriatus, Pterostichus madidus, and Calathus spp., are associated with heathland or chalkland and Amara equestris is particularly associated with stony or sandy ground in heathland or chalkland environments (Lindroth 1974; Luff 2007). A small number of water beetles such as Hydroporus spp. and Cyphon spp. were also recovered.

\section{S3 (Fig. 11)}

The upper $(0-30 \mathrm{~cm})$ and lower $(30-52 \mathrm{~cm})$ plant macrofossil samples from site S3 (Table 9) comprise largely similar vegetation communities, with a greater number and diversity of macrofossils present in the upper sample. A number of herbaceous taxa in the upper plant macrofossil sample are characteristic of areas of open grassland, pasture and disturbed ground. The species are similar to those recorded for Site S1.1, with the additional presence of Rumex sp (docks) and Aphanes sp (Parsley-pierts) in the plant macrofossil record and taxa such as Plantago lanceolata, Rumex, Potentilla-type, Lactuceae and Brassicaceae consistently found in the pollen record.

Although a number of taphonomic processes may have been involved in the formation of the organic deposits within the mine, it is interesting to note that a significant proportion of the plant remains from both sites are indicator species for the use of grassy moorland turfs from archaeological deposits, as defined by Hall (2003). In particular, bracken, mosses and heather are frequent elements, with Potentilla, Leontodon, Prunella vulgaris, Ranunculus, 
Rumex, Viola and Cenococcum geophilum, listed as characteristic above and below ground species. Turfs were used for a variety of purposes, and it is feasible that locally-cut turfs were brought into the mine as packing material or for retaining water.

Calluna and Ericaceae pollen and macrofossils are abundant, suggesting that ericaceous plants have become well established locally. However, both decline from sub-unit 11 in the pollen record as Poaceae, Potamogeton natans-type and Equisetum all increase dramatically. The latter two taxa are indicative of open water and/or very wet conditions. Abundant Callitriche sp (water-starwort), which occurs with a minor element of Lemna sp (duckweed) in the plant macrofossils, indicates shallow pools of temporary or permanent water. Associated damp ground taxa, predominantly comprising species of Juncus and Rorippa, occur in the plant macrofossil record. Taxa such as Filipendula, Apiaceae and Cyperaceae are regular members of wet grassland/rough meadow communities and are present particularly in the upper sub-units of the $\mathrm{S} 3$ pollen record.

Beetle species associated with rough grassland and open areas occur in some numbers. Typical of this kind of landscape is the range of ground beetles recovered such as the Carabus, Trechus, Calathus and Amara species (Table 5). A number of species such as the ground beetle Trichocellus placidus and the weevil Trachyphloeus alternans are associated with sandy open areas, often within chalkland and heathland, with the latter species sometimes associated with rock rose (Helianthemum nummularinum Mill). Other species commonly occur on plants within rough grassland; for example, Apion frumentarium is associated with docks, Alophus triguttatus, Gymnetron spp. with plantain (Plantago spp.) and Sitona hispidulus with clover (Trifolium spp.). There is also some indication for heather in the area, since this is the food plant of the small weevil Micrelus ericae. Very small numbers of Aphodius spp. dung beetles were recovered from samples at sub-unit 11 at Site S3, which suggests that grazing animals may have been present.

Cenococcum geophilum, Betula and Rubus in the plant macrofossil record provide evidence for scattered trees and shrubs and scrub/woodland soils. Initially total tree and shrub pollen percentages are similar to those recorded at S1.1. However, they decline permanently to less than 25\% TLP by sub-unit 3 in S3 and remain around that value until they drop slightly once again between sub-units 14 and 15. Quercus is most adversely affected. Corylus avellana-type is the dominant shrub taxa fluctuating between 5 and 10\% TLP. Small fluctuations also affect Alnus and Betula, but the percentages of both taxa show minor increases between sub-units 7 and 11 (Fig. 11). The permanent loss of Quercus may well be related to its use in the mine, especially as herbaceous pollen associated with pasture and/or 
disturbed ground also decline. The increased presence of heathland, suggested by higher percentages of Calluna and Ericaceae, replaces woodland as the major type of local land use. Given the much lower percentages of arboreal pollen in this section, it is possible that it represents a different and probably later time period than $\mathrm{S} 1.1$.

There is also evidence for trees or woodland in the area in the beetle record. Both Agathidium atrum and A. sphaerulum are associated with decaying wood, leaf litter and moss in woodland. Cylindronotus laevioctostriatus was also recovered in some numbers at site S3 and indicates the presence of rotting wood and heather stems. The wood boring scolytid Dryocoetes villosus was recovered at $38-30 \mathrm{~cm}$ (Table 5, sub-units 9A-6) and is associated with a wide range of hard-wood trees and is more likely to occur on live trees than timbers.

\section{Discussion}

The S1.1 deposits comprise waste spoil from mining and the back-filling or infilling (through possible slumping) of the excavated workings, as well as possibly residue from the crushing and washing process by which copper ore was removed (Fig. 5 -S1.1). Whether this came from work carried out underground, or from sediments washed down into the workings, is unknown, but the radiocarbon dates clearly place these deposits in the Bronze Age. While not directly radiocarbon-dated, the layers of finely banded clay-silt material (unit 104) sandwiched in-between the dated units are indicative of ponding during a period between two phases of back-filling or natural infilling of the workings.

The macro- and micro-fossil records support the idea that the unit 104 deposits were washed-in from the surface. The pollen, plant macrofossil and insect faunas recovered clearly have an origin outside of the mine. There has been little intensive research into the beetle faunas from cave and mine sites, but a few species have been recorded from both the thresholds and interior of underground systems. It appears that a number of ground beetles such as Trechoblemus micros (Hbst.) and Trechus fulvus Dej., the staphylinid Quedius mesomelinus (Marsh.) and the catopid Choleva spp. have been recorded regularly in caves (Cambrian Caving Council 2010), but such taxa are noticeably absent from the Mynydd Parys insect faunas. This suggests that these faunas along with pollen and plant macrofossils have probably been swept into the mine, possibly during floods or more gradually as water percolated from the surface. These insects, pollen and plant macrofossils suggest, therefore, that the area around the mine itself was mainly open grassland and rough ground with some limited woodland. 
It is not clear how representative these assemblages are of the surrounding landscape. The beetle faunas are comparatively small (with a minimum number of individuals ranging between two and 145 identifications, representing between two and 41 different taxa) and there are issues over how these insects' remains and the macro- and microfossils may have entered the mine and their resultant taphonomy. Despite these reservations, it does appear that generally there are fewer insect species associated with woodland towards the top of the deposit than lower down. Taken at face value this provides limited evidence to support a progressive clearance of the landscape over this period of time, which broadly confirms the results of the pollen analysis.

Pollen preservation appears to have been largely unaffected by any transportation process(es). Whilst the condition of pollen grains show signs of deterioration, identifiable counts of 300 TLP were achieved throughout the sequence (Delcourt and Delcourt 1980; Jones et al. 2007). Pollen grain damage (broken, crushed, corroded and/or degraded) was recorded at both sections S1.1 and S3, with crushing and degradation most likely caused during transportation in water. Some of the corroded, crushing and broken grains will reflect in-wash and possible reworking of pollen contained within eroded material (cf. Tipping 1987; Wilmshurst \& McGlone 2005a; 2005b). Degraded grains are commonly crushed or crumpled, which also indicates that they have been transported and are then redeposited (Cushing 1967; Lowe and Walker 1997). Notwithstanding these issues, the proportion of unidentifiable grains is below some of the thresholds suggested for data being unrepresentative from soils (Bunting et al. 2001; Tipping et al. 1994).

The seven samples from S3 produced a series of insect faunas that are also essentially similar to that recovered from S1.1 However, it is noticeable that the insect remains were recovered in high numbers and were better preserved moving up the section. This is unexpected and runs counter to the nature of preservation in most archaeological deposits, where preservation usually is best at the base of the material sampled.

\section{Conclusion}

The palaeoenvironmental records from Mynydd Parys confirm that the landscape surrounding the mine was largely open with areas of heathland and wet grassland with some pools of water. Deciduous woodland was present, mainly comprising oak and hazel. A permanent decline in woodland was recorded at site S3, with oak being most affected. Otherwise, the tree and shrub pollen record is characterised by small-scale fluctuations of oak, hazel, birch and alder, all known to have been used in prehistoric mines. 
Notwithstanding taphonomic and dating issues, trends in both pollen diagrams are similar to those recorded in other pollen diagrams close to prehistoric mining and metalworking sites, in particular small-scale fluctuations of Quercus, Corylus, Alnus and Betula (Mighall \& Chambers 1993; Mighall et al. 2017). It is possible that these fluctuations are the result of exploitation of local woodland for timber and charcoal. The permanent decline in tree and shrub pollen at Site S3 contrasts with evidence from other Bronze Age mines in Wales and Ireland which suggests woodland was not severely cleared (Mighall \& Chambers 1993; Mighall et al. 2017). However, all these mines including Mynydd Parys, did not operate in isolation and agricultural activities, in particular grazing, occurred as part of a dual economy. 


\section{AUTHORS’ ADDRESSES}

David A Jenkins

Llys Geraint, Bethesda, Gwynedd, LL57 4AX

Formerly Reader in Soil Micromorphology, Department of Bio-Chemistry and Soil Science, Bangor University, Bangor, Wales

Simon Timberlake

Cambridge Archaeological Unit, Department of Archaeology, University of Cambridge, 34A Storeys Way, Cambridge, CB3 ODT

Early Mines Research Group, Ashtree Cottage, 19, The High Street, Fen Ditton,

Cambridgeshire, CB5 8ST

Andrew Davidson

Gwynedd Archaeological Trust, Craig Beuno, Garth Road, Bangor, Gwynedd LL57 2RT

Jane Kenney

Gwynedd Archaeological Trust, Craig Beuno, Garth Road, Bangor, Gwynedd LL57 2RT

Peter Marshall

Scientific Dating Team, Historic England, 4th floor, Cannon Bridge House, 25 Dowgate Hill, London EC4R 2YA

Tim Mighall

Department of Geography \& Environment, School of Geosciences, University of Aberdeen, Elphinstone Road, Aberdeen, AB24 3UF

David N. Smith

Department of Classics, Ancient History \& Archaeology, The University of Birmingham, Edgbaston, Birmingham, B15 2TT

Kalla Mal

Department of Classics, Ancient History \& Archaeology, The University of Birmingham, Edgbaston, Birmingham, B15 2TT

Charlotte O'Brien

Archaeological Services, Durham University, Department of Archaeology, South Road, Durham, DH1 3LE 

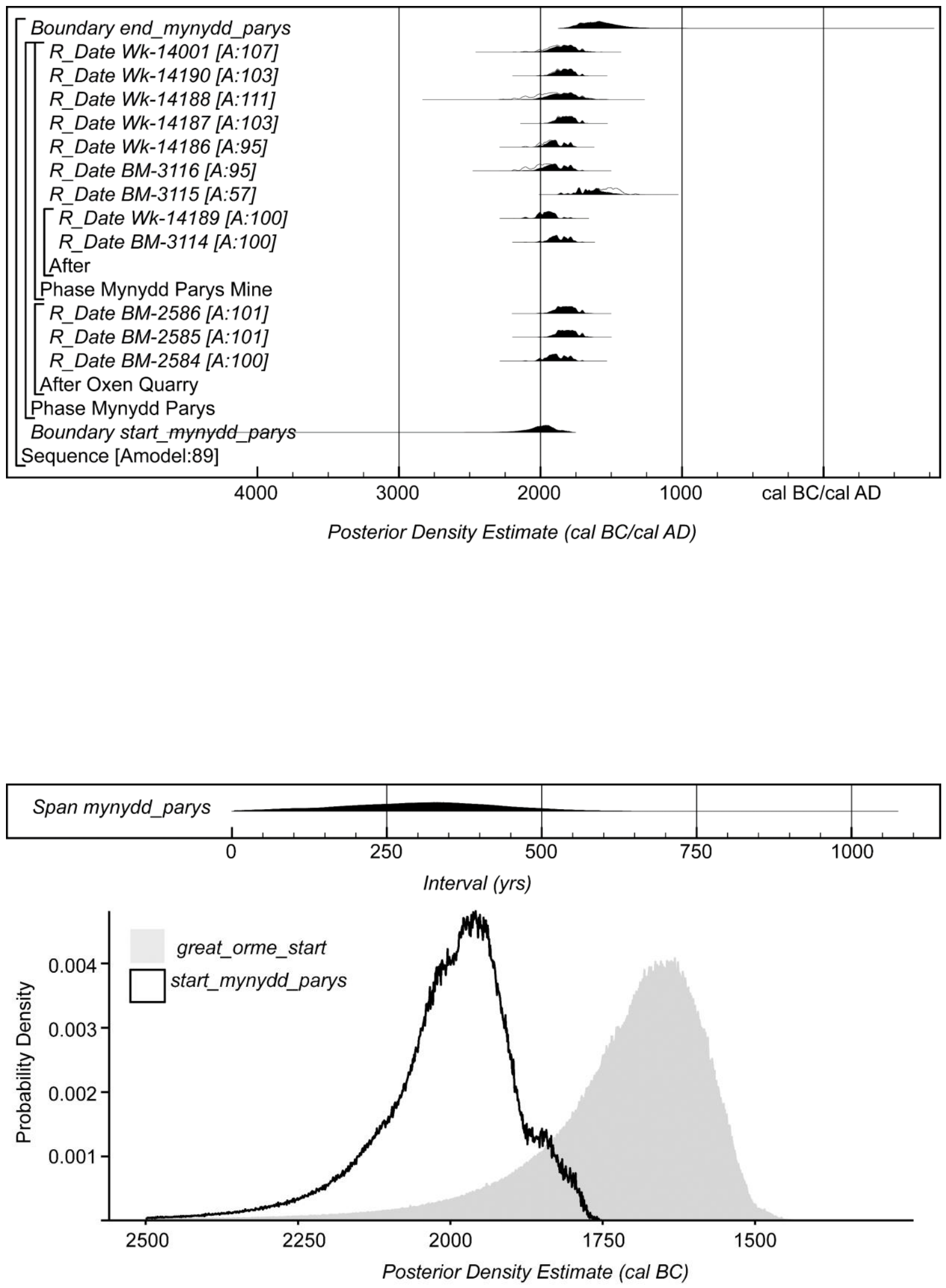

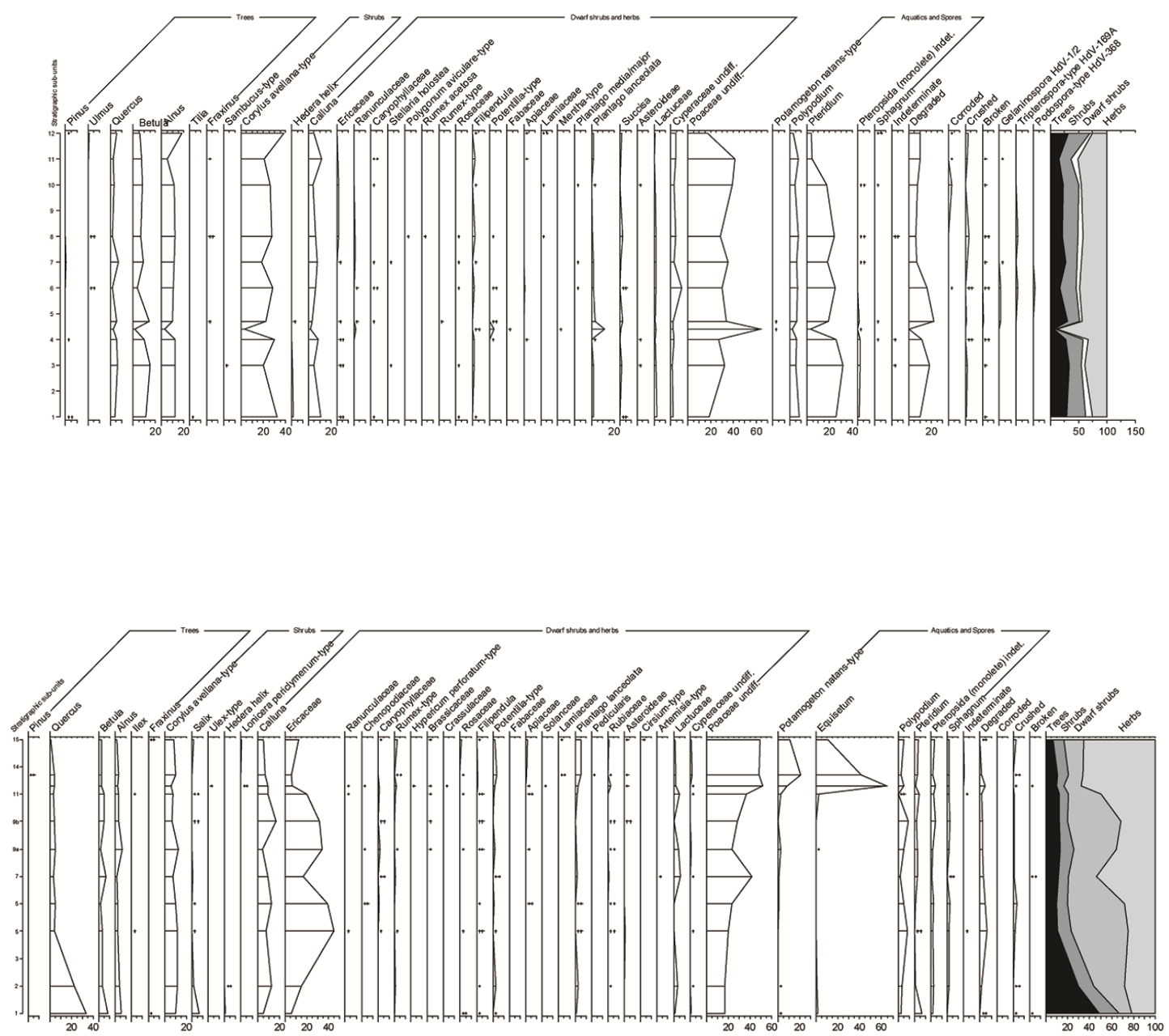


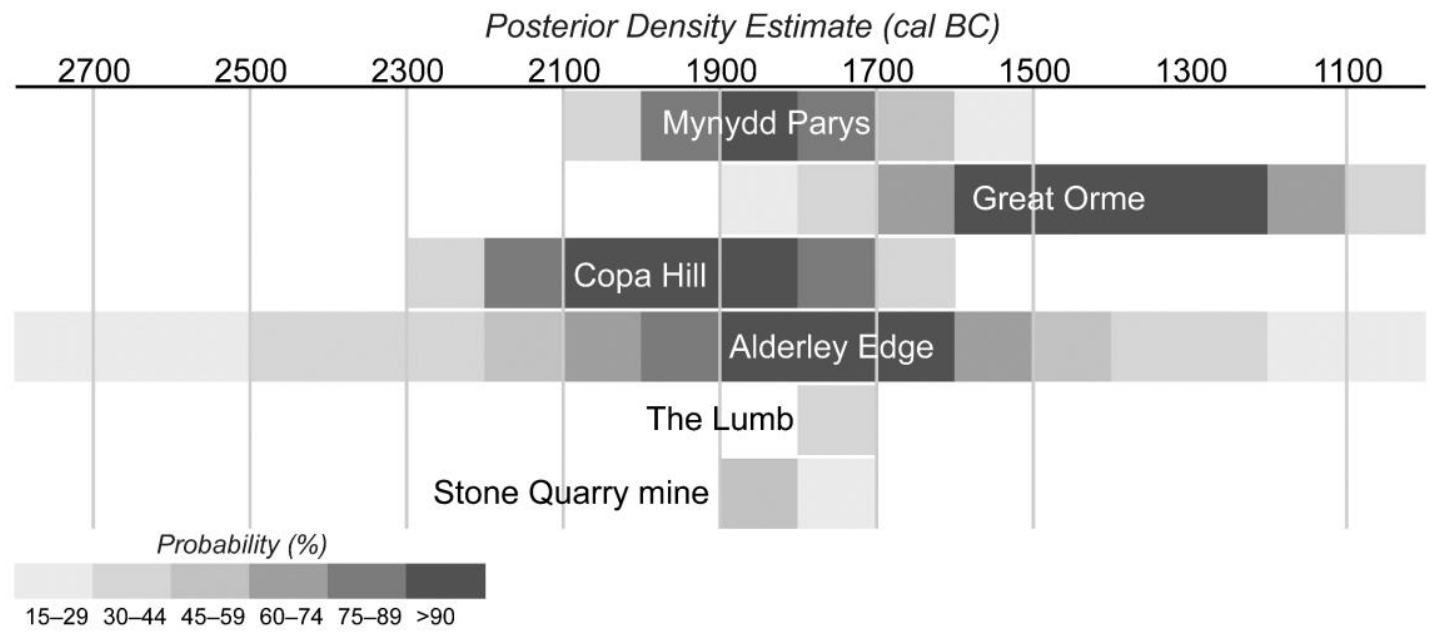

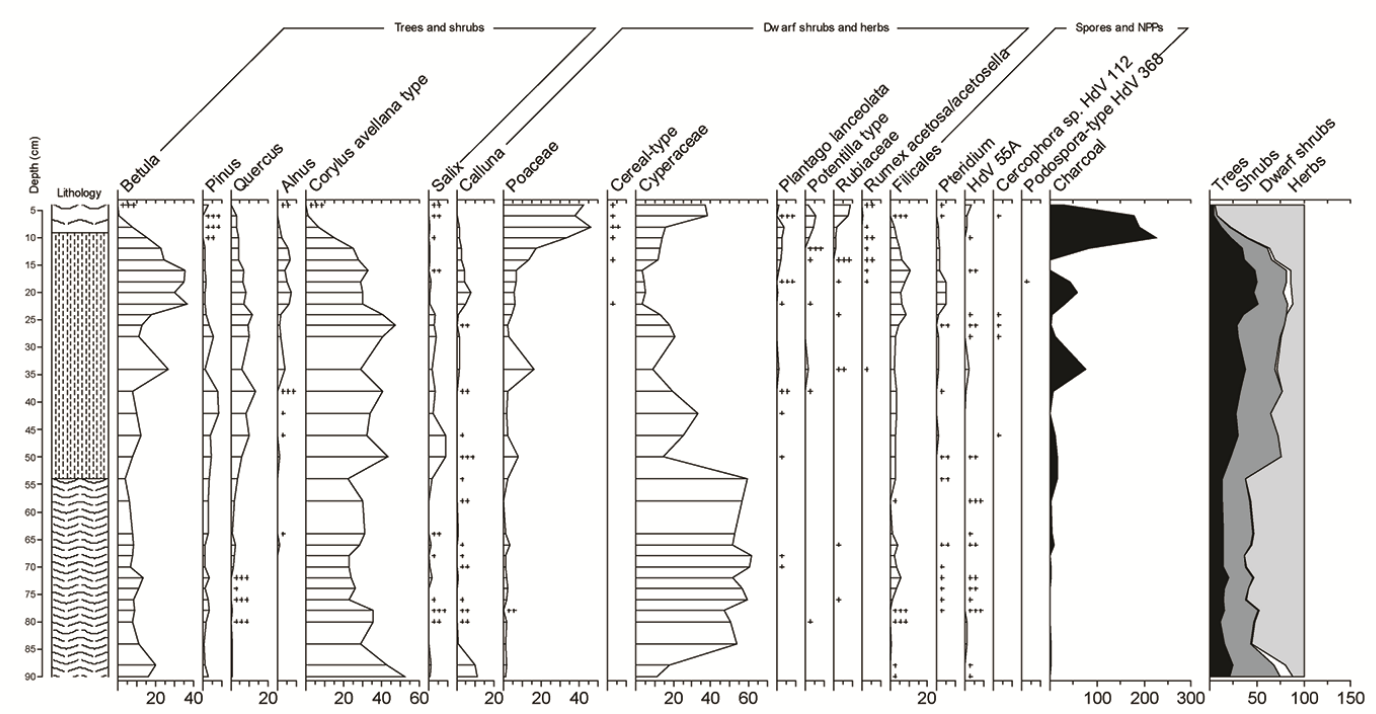




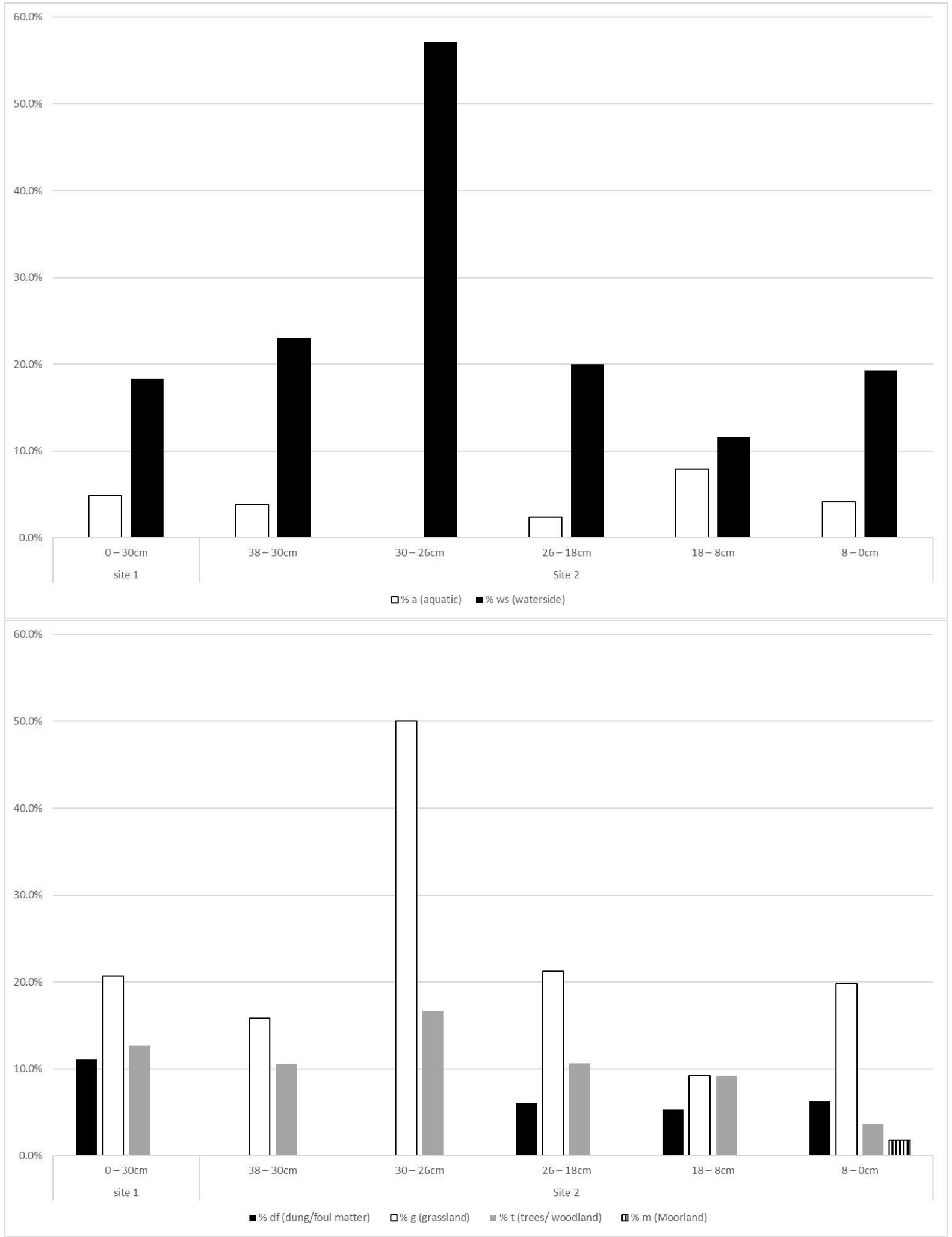




\section{Figure captions}

Fig. 1. Location map for the mines on Mynydd Parys.

Fig. 2. Map of above ground Bronze Age sites 1 to 4 on Mynydd Parys showing distribution of mauls found on the surface and location of underground sites in relation to surface features (superimposed on the 1924 OS 25 inch map).

Fig. 3. Plan of the 10, 16 and $20 \mathrm{fm}$ levels with above a 3D sketch map of the underground Bronze Age sites (S1-7).

Fig. 4. One suggested method of working from the surface using inclined opencasts (hatched) excavated by firesetting. NB most of the mining will have taken place within the oxidised/ supergene zone above the pre-mining water table (drawing S. Timberlake, after Jenkins 1995, 36).

Fig. 5. Sections at underground sites S1 and S3 with lab numbers for dated samples marked.

Fig. 6. Hammerstones recovered in 1988 from surface excavations carried out at the Oxen Quarry - a Site 3 Trench D (001); b Split and notched hammerstone re-used from Site 2 surface find; c Hammer spall surface find; d Hammerstone with a faint rill around its middle modified to take a handle Site 3 Trench A (drawn by Brenda Craddock).

Fig. 7. Probability distributions of dates from Mynydd Parys. Each distribution represents the relative probability that an event occurs at a particular time. For each radiocarbon date, two distributions have been plotted: one in outline which is the result of simple radiocarbon calibration, and a solid one based on the chronological model used. The other distributions correspond to aspects of the model. For example, the distribution 'start_mynydd_parys' is the estimate for when mining activity started. The large square brackets down the left-hand side of the diagram and the OxCal keywords define the overall model exactly.

Figure 8. Probability distribution for the number of years during which mining activity occurred at Mynydd Parys, derived from the model defined in Fig. 10. 
Fig. 9. Probability distributions of estimates for the beginning of mining activity at Mynydd Parys (derived from Fig. 10) and the Great Orme (derived from the model described in Timberlake \& Marshall (2013, fig 4)).

Fig. 10. Pollen diagram for S1.1, Unit 104.

Both pollen diagrams, drawn using Tilia and Tilia.graph version 2.0.b4 (Grimm, 1991-1993), are presented as percentages of total land pollen (TLP), excluding spores and aquatics. Spore and aquatics are also expressed as a percentage of total land pollen. A cross denotes one pollen grain. Plant nomenclature follows that of Stace (1991) and takes into account the problems of categorising plant species on the basis of their pollen morphology (see Bennett et al., 1994). Summary curves for trees, shrubs (constituting arboreal pollen, AP), dwarf shrubs and herbs (non-arboreal pollen, NAP) are shown.

Fig. 11. Pollen diagram for S3.

Fig. 12. Schematic diagram showing the periods of use of dated Bronze Age mining sites (Peter Marshall).

Fig. 13. Pollen diagram from Rhosybol.

Fig. 14. The proportions of the aquatic ecological groups from Mynydd Parys.

Fig. 15. The relative proportions of the terrestrial ecological groups from Mynydd Parys. 


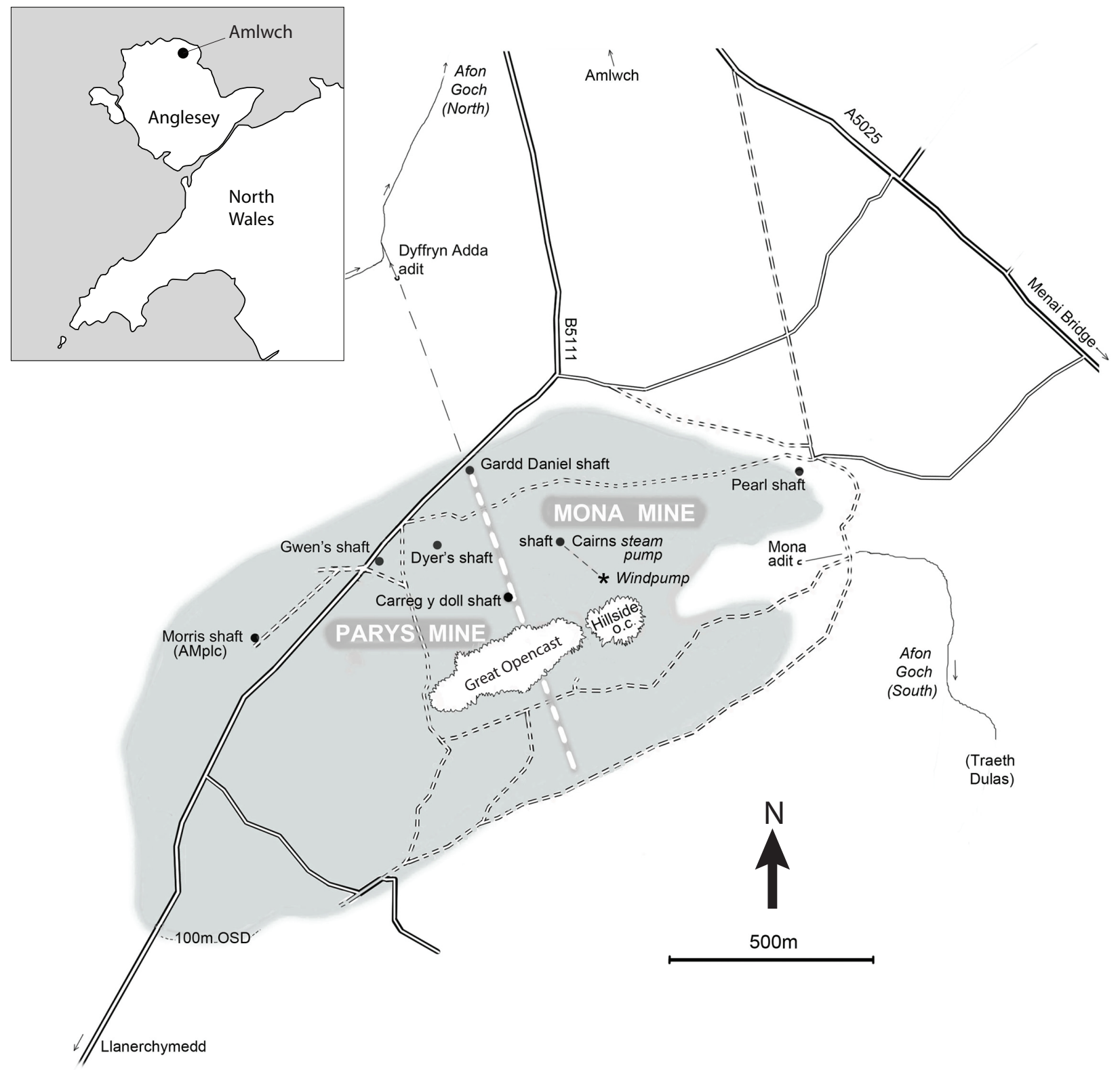




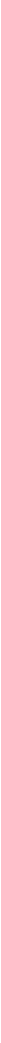



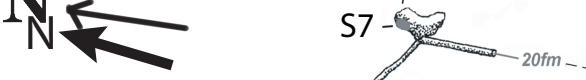

footway
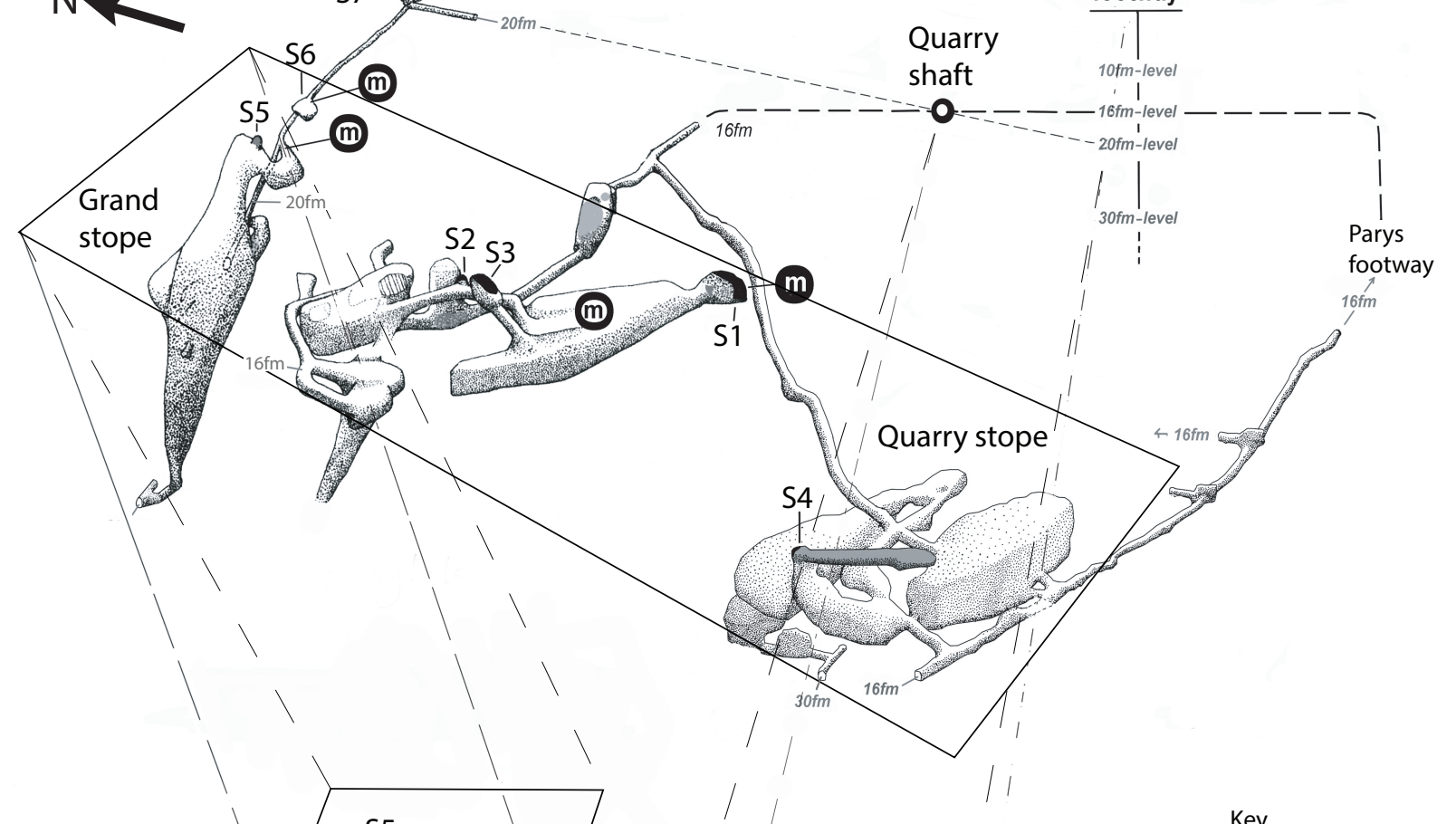

Key

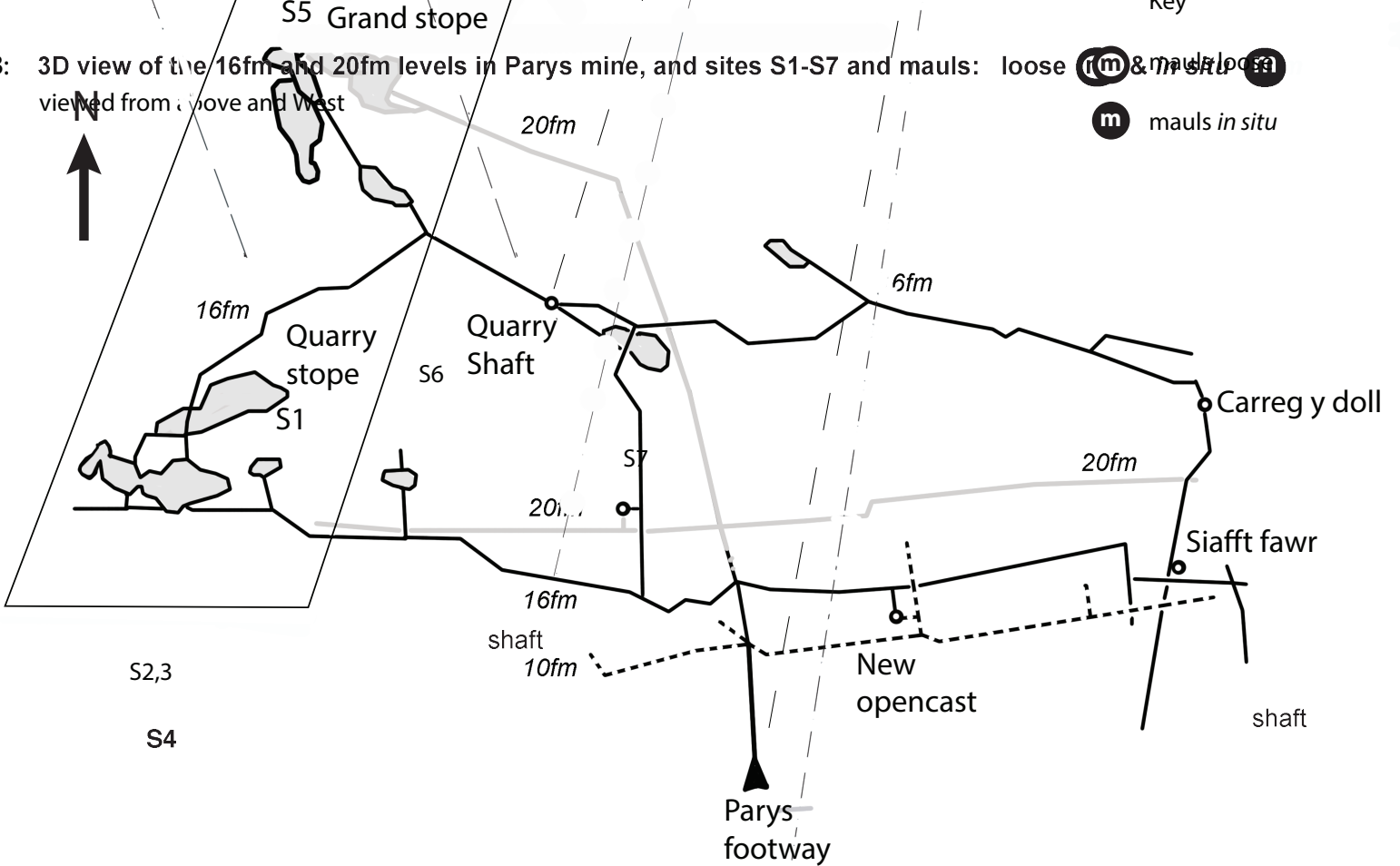




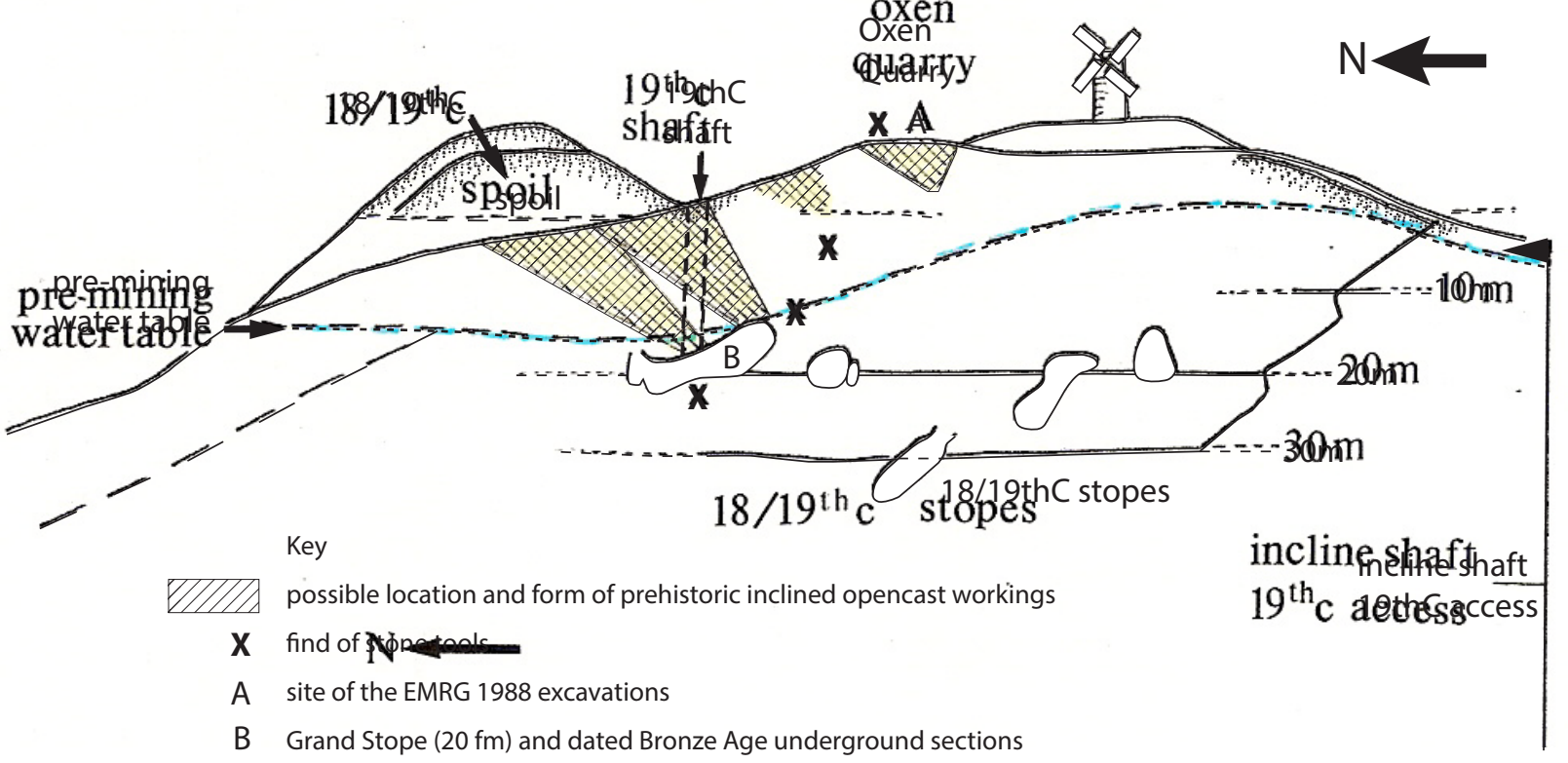



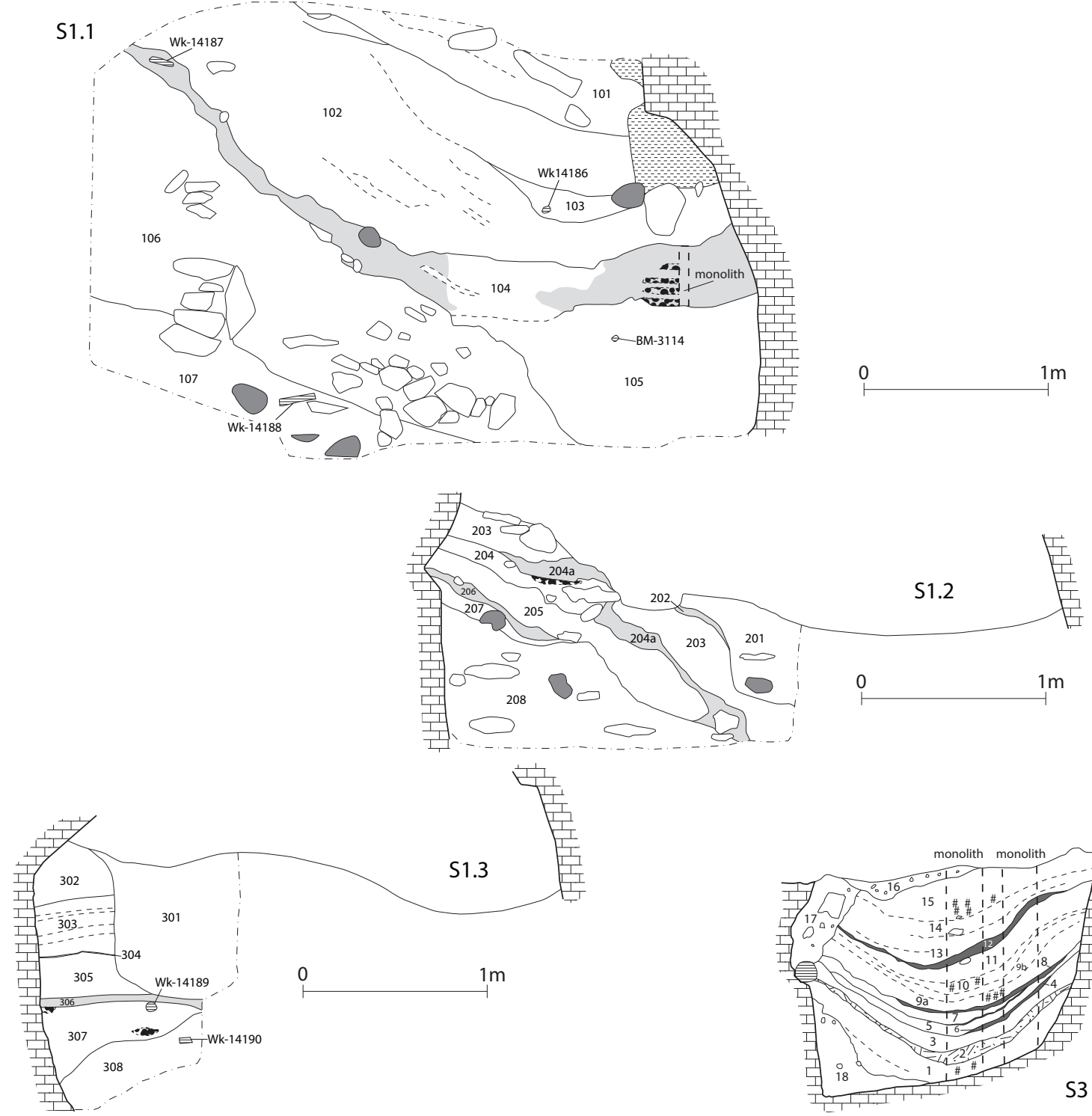

Key
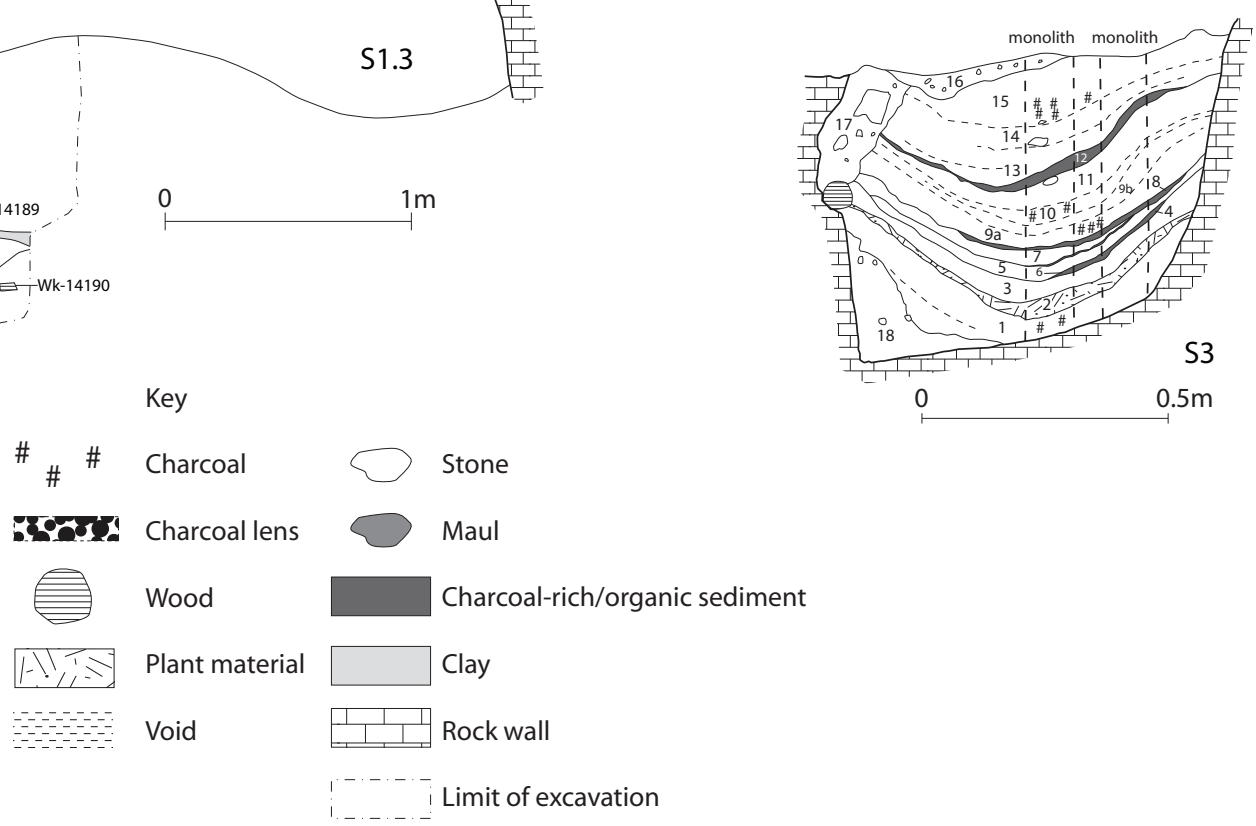
